\title{
The changing course of the Amazon River in the Neogene: center stage for Neotropical diversification
}

\author{
James S. Albert ${ }^{1}$, Pedro Val ${ }^{2,3}$ and Carina Hoorn ${ }^{4}$
}

We review geological evidence on the origin of the modern transcontinental Amazon River, and the paleogeographic history of riverine connections among the principal sedimentary basins of northern South America through the Neogene. Data are reviewed from new geochronological datasets using radiogenic and stable isotopes, and from traditional geochronological methods, including sedimentology, structural mapping, sonic and seismic logging, and biostratigraphy. The modern Amazon River and the continental-scale Amazon drainage basin were assembled during the late Miocene and Pliocene, via some of the largest purported river capture events in Earth history. Andean sediments are first recorded in the Amazon Fan at about 10.1-9.4 Ma, with a large increase in sedimentation at about 4.5 Ma. The transcontinental Amazon River therefore formed over a period of about 4.9-5.6 million years, by means of several river capture events. The origins of the modern Amazon River are hypothesized to be linked with that of mega-wetland landscapes of tropical South America (e.g. várzeas, pantanals, seasonally flooded savannahs). Mega-wetlands have persisted over about 10\% northern South America under different configurations for $>15$ million years. Although the paleogeographic reconstructions presented are simplistic and coarse-grained, they are offered to inspire the collection and analysis of new sedimentological and geochronological datasets.

Keywords: Biostratigraphy, Geochronology, Landscape Evolution Model, River capture, Transcontinental Amazon.

Este trabalho é uma revisão das evidências geológicas sobre a origem do moderno rio Amazonas transcontinental, e a história paleogeográfica das conexões ribeirinhas entre as principais bacias sedimentares do norte da América do Sul durante o Neógeno. São revisados novos conjuntos de dados geocronológicos usando isótopos radiogênicos e estáveis, e de métodos geocronológicos tradicionais, incluindo sedimentologia, mapeamento estrutural, exploração sísmica e bioestratigrafia. $\mathrm{O}$ atual rio Amazonas e sua bacia continental se formaram durante o final do Mioceno e do Plioceno, através de alguns dos maiores eventos de captura de rio na história da Terra. Os sedimentos andinos são registrados pela primeira vez no leque fluvial do Amazonas por volta de 10,1-9,4 Ma, com um grande aumento na sedimentação a cerca de 4,5 Ma. O rio Amazonas transcontinental, portanto, se formou durante um período de cerca de 4,9 a 5,6 milhões de anos, por meio de vários eventos de captura de rios. Acredita-se que as origens do moderno rio Amazonas estejam ligadas às paisagens de inundação da América do Sul tropical (por exemplo, várzeas, pantanais, savanas sazonalmente inundadas). As áreas pantanosas persistiram em cerca de $10 \%$ do norte da América do Sul sob diferentes configurações por mais de 15 milhões de anos. Embora as reconstruções paleogeográficas apresentadas sejam simplistas, elas são oferecidas para inspirar a coleta e análise de novos conjuntos de dados sedimentológicos e geocronológicos.

Palavras-chave: Amazonas transcontinental, Bioestratigrafia, Captura de rio, Geocronologia, Modelos de evolução de paisagem.

\section{Introduction}

The principle of uniformitarianism avers "the present is the key to the past", asserting the universality of natural laws and processes across space and through time. This principle is a pillar of the historical sciences, upon which rest modern practices in the fields of geomorphology, paleontology and biogeography (Simpson, 1963; Stanley, 1979; Shea, 1982).
In these sciences the reverse is also often just as important, where the current state of a geological or biological system can only be fully understood in light of conditions as they were in the past (Webb et al., 2002; Fine, Ree, 2006; Kissling et al., 2012; Albert, Antonelli, 2017). Celebrated examples from biogeography include the biotic assemblages of the southern continents following the breakup of Gondwana (Cracraft, 1973; Linder, Crisp, 1995; Lundberg et al., 1998;

\footnotetext{
${ }^{1}$ Department of Biology, University of Louisiana at Lafayette, Lafayette. LA 70504, USA. jalbert@louisiana.edu, @ohttps://orcid.org/00000001-5477-1749 (corresponding author).

${ }^{2}$ Geosciences Research Division, University of California, San Diego, CA La Jolla 92093, USA. pval@ufop.edu.br

${ }^{3}$ Departamento de Geologia, Escola de Minas, Universidade Federal de Ouro Preto, Ouro Preto 35400-000, MG, Brazil.

${ }^{4}$ Institute for Biodiversity and Ecosystem Dynamics, University of Amsterdam, P.O. Box 94248, 1090 GE Amsterdam, The Netherlands. M.C.Hoorn@uva.nl
} 
Sparks, Smith, 2004), the Greater Antilles by means of coordinated dispersal under the influence of geographically persistent dispersal vectors (Iturralde-Vinent, MacPhee, 1999; Tagliacollo et al., 2017), and the response of the North American biota to Pleistocene ice-age cycles (Webb, 1977; Knouft, Page, 2003; Pielou, 2008).

Nowhere on Earth does history play a more important role in understanding the coevolution of landscape and life than in Greater Amazonia, a biodiversity province that extends over 8.4 million $\mathrm{km}^{2}$ of Amazon and Orinoco lowlands and adjacent portions of the Guiana and Brazilian Shields (Albert et al., 2011a; Reis et al., 2016; Van der Sleen, Albert, 2017). The Amazon rainforest ecosystem and Amazon drainage basin are the largest of their respective kinds on Earth, being home to one of the greatest concentrations of species diversity on the planet (Wallace, 1889; Pimm et al., 2014). Most Amazonian plant and animal lineages have ancient origins in the super-greenhouse world of the Late Cretaceous (100-66 Ma) and Paleogene (66-23 Ma), and the biota achieved approximately modern dimensions during the Neogene (23-2.6 Ma; Lundberg et al., 1998; Antonelli et al., 2009, 2010; Albert et al., 2011b; López-Fernández, Albert, 2011). In general, continental-scale systems like the Amazon rainforest and drainage basin do not form all at once, but rather accumulate under the influence of numerous contributing factors over periods of millions of years.

The great drainage basins of tropical northern South America (NSA) were assembled during the Neogene, during which time many important geographic features of the modern world assumed their modern configurations (Potter, Hamblin, 2006; Potter, Szatmari, 2009; Horton, 2017). These include formation of the modern latitudinal climate regimes (Knorr, Lohmann, 2003), world's tallest mountain ranges (e.g. Alps, Andes, Himalayas, etc.), and largest river systems (e.g. Amazon, Orinoco, Brahmaputra, Congo, Danube, Yangtze; Courtillot et al., 2003; Potter, Szatmari, 2009). As with all these drainages, the present-day Amazon formed by the process of river capture (Goudie, 2005; Ashworth, Lewin, 2012; Winn et al., 2017; Albert et al., 2018). River capture is a geomorphological process (sensu Gilchrist, Summerfield, 1991; Bishop, 2007) operating perennially on most continental surfaces, whereby a portion of one river basin is diverted into a different drainage, thereby moving the watershed boundary between the two basins. River capture alters connectivity patterns among portions of river networks through time (Bishop, 1995; Brookfield, 1998; Albert, Crampton, 2010; Willett et al., 2014) and, as a consequence, affects evolutionary diversification in obligate riverine taxa by separating and merging segments of drainage networks (Wilkinson et al., 2010; Albert et al., 2017).

The effects of river capture on speciation and extinction are complex and intertwined. By subdividing species geographic ranges river capture isolates populations on either side of a new watershed divide, thereby promoting speciation. However, because these isolated populations have smaller populations sizes, river capture can serve to increase extinction risk. Yet curiously, river capture can also inhibit the processes of speciation and extinction by facilitating dispersal (i.e. geographic range expansion) among populations in newly merged river segments. As a result of these complex effects, river capture has been implicated in the formation of high freshwater diversity in many regions and taxa (see review in Albert et al., 2018). River capture has contributed substantially to diversification in many aquatic and terrestrial Amazonian taxa that are ecologically restricted to rivers, floodplains, and riparian woodlands (e.g. Aleixo, 2004; Albert et al., 2006; Lovejoy et al., 2010; Albert, Carvalho, 2011; Ribas et al., 2012; Roxo et al., 2014; Tagliacollo et al., 2015). The role of river capture in biotic diversification has also been demonstrated in many other regions of the world (Stanford, Ward, 1993; Robinson et al., 2002; Ward et al., 2002; Burridge et al., 2006; Smith et al., 2010; Carrea et al., 2014; Craw et al., 2016).

As with many of Earth's ancient tropical biotas (e.g. Wiens, Donoghue, 2004; Cowman, Bellwood, 2011), most of the species-rich Amazonian clades and ecosystems are older than the geographic conditions in which they live today (Hoorn et al., 2010a, 2010b; Albert et al., 2011a; Graham, 2011). Although the precise age of the modern west-to-east-flowing transcontinental Amazon River system is still incompletely understood, the main events are estimated to have occurred in the Neogene. Published age estimates for the origin of the transcontinental Amazon range over two orders of magnitude, from 0.1 to $12.6 \mathrm{Ma}$ (Tab. 1). These dates have been estimated from a variety of geochronological, sedimentological and paleontological studies, using data obtained from drill cores, outcrops, and wells located in the Amazon and Orinoco basins, and from offshore sites in the Amazon Fan and Ceará Rise, an oceanic ridge east of the Amazon River mouth (e.g. Dobson et al., 2001; Figueiredo et al., 2009, 2010; Heinrich, Zonneveld, 2013; Hoorn et al., 2017). Fig. 1 illustrates the major sources of sediment types delivered to the mouth of the Amazon, and Fig. 2 provides a summary of information from sedimentary cores located near the mouth of the Amazon.

Beginning in the 1990s, Hoorn and colleagues advanced a general timeline in which the modern transcontinental Amazon was assembled by means of an extraordinarily large mega river capture event during the late Miocene (c. 11-9 Ma; see Hoorn, 1993; Hoorn et al., 1995; Lundberg et al., 1998; Wesselingh, Hoorn, 2010). A mega-capture is a river capture event involving more than $1,000 \mathrm{~km}^{2}$, or about $0.29^{\circ}$ latitude and longitude at the equator (Albert et al., 2018), a spatial scale that is expected to affect third-order streams and larger, and therefore rates of net lineage diversification in obligate riverine taxa (Tedesco et al., 2012). This mega-capture event is the largest of its kind ever proposed, transferring approximately 1,600,000 $\mathrm{km}^{2}$ of watershed area from the sub-Andean foreland to the eastern Amazon (Albert et al., 2018). The capture process involved diverting Caribbean-draining basins of the Western Amazon into the Atlantic-draining Eastern Amazon, and a concomitant 

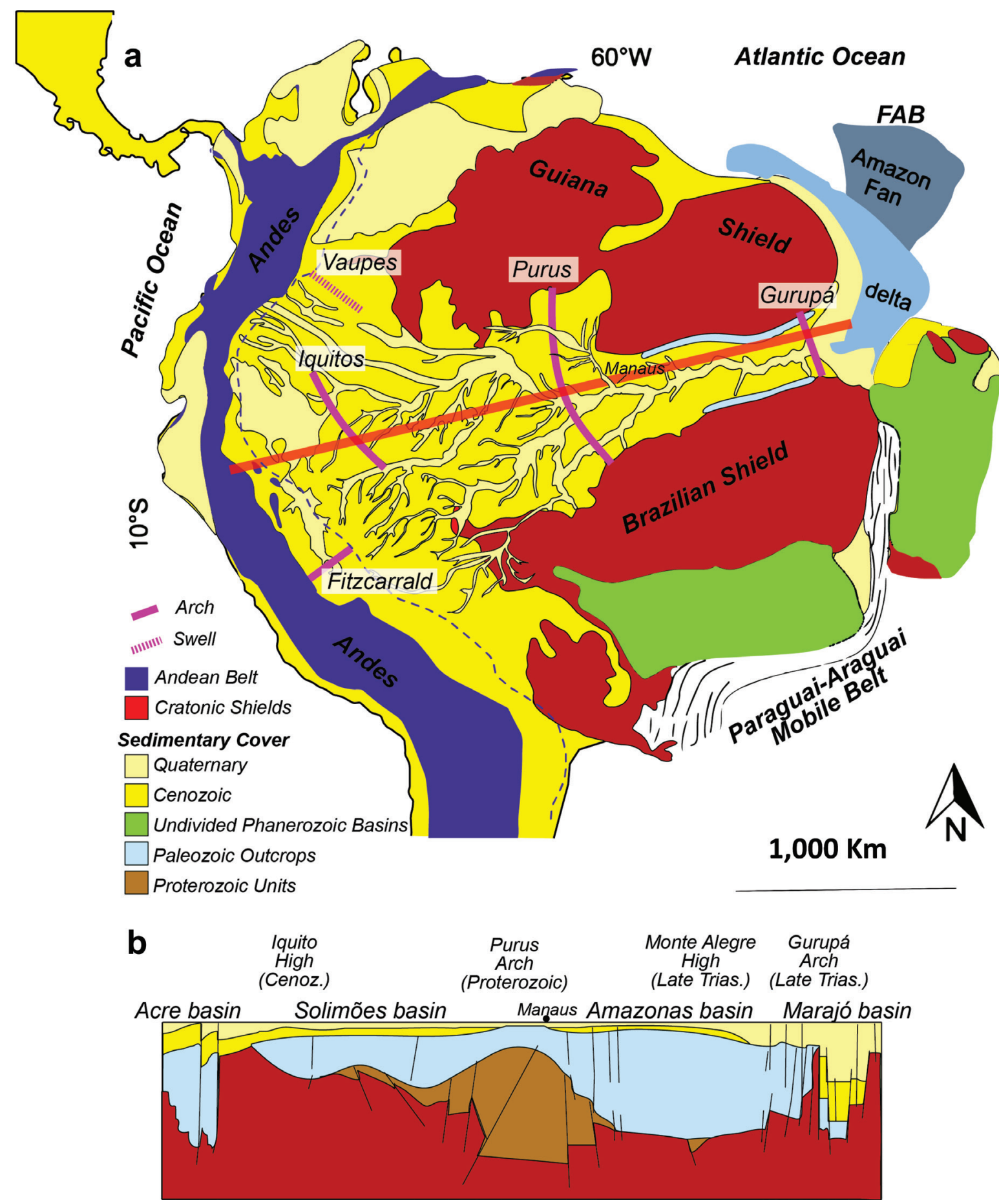

Fig. 1. Geological map of northern South America. a. Geological units that formed the provenance area for the sediment input into the Amazon subaqueous delta and submarine fan (adapted from Hoorn et al., 2017). FAB, Foz do Amazonas Basin. b. Schematic longitudinal section (orange bar) of the Amazon river basin showing sedimentary basins and structural arches (adapted from Wanderley-Filho et al., 2010; Caputo, Soares 2016).

separation of western Amazonian basins from the Orinoco basin by the rise of the Vaupés Arch (Mora et al., 2010). This river capture event diverted Andean waters to flow eastwards across the whole of northern South America and into the Atlantic, depositing Andean-derived sediments at or near the mouth of the modern Amazon River.
The formation of the transcontinental river system occurred by breaching or transgression of the Purús Arch, a subsurface high with Paleozoic origins, which is formed part of the eastern watershed or margin of the sub-Andean foreland during the Cretaceous and Paleogene (Mora et al., 2010; Wanderley-Filho et al., 2010; Hurtado et al., 2018; see also 

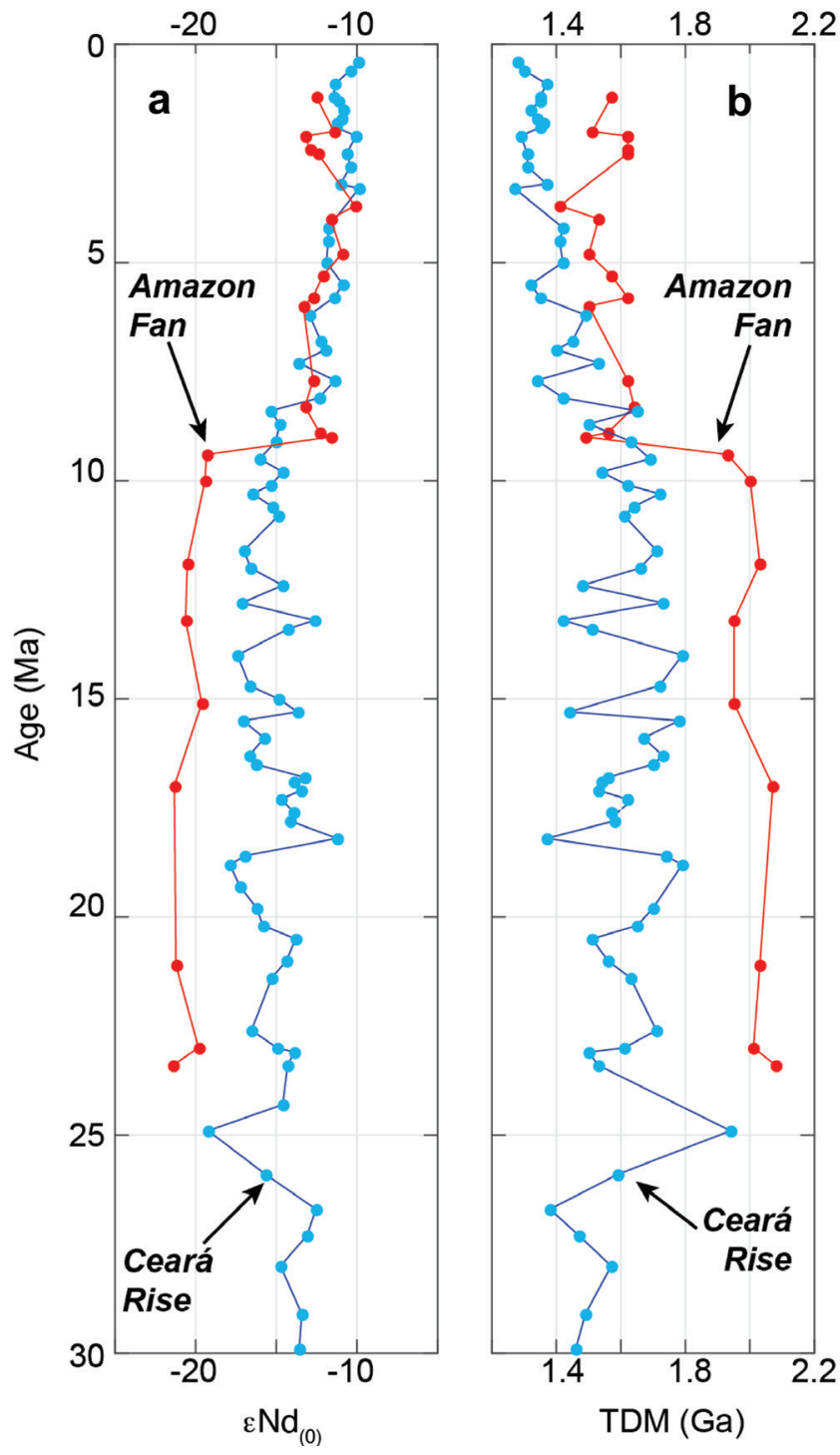

Fig. 2. Summary of terrigenous signals from drilling cores near the mouth of the Amazon River. Sediment dating of cores in the Amazon Fan (red; Hoorn et al., 2017) and Ceará Rise (blue; van Soelen et al., 2017). a. Ratios of stable Neodymium isotopes expressed in epsilon notation: $\mathrm{eNd}(0)$. b. Crustal residence times ( $\boldsymbol{\tau} \mathrm{DM})$. Note values of both parameters change through time according to the provenance of the preserved terrigenous material. $\mathrm{eNd}(0)<-15$ and a $\tau \mathrm{DM}>1.67 \mathrm{Ga}$ reflect a primarily cratonic source. Both the Amazon Fan and Ceará Rise record significant changes away from a cratonic source (towards an Andean source) by c. 9-7 Ma.

below). Understanding the precise timing and sequence of this geomorphological event, contributing to the formation of the expansive Amazon catchment, is of central concern to the study of Neotropical biodiversity (Cracraft, 1985; Lundberg, 1998; Tedesco et al., 2005; Hoorn et al., 2010a; Albert et al., 2011; Antonelli, Sanmartín, 2011; Dias et al., 2014; Smith et al., 2014). Constraining age estimates on the origin of the transcontinental Amazon River informs models on the diversification of taxa with geographic ranges that extend over large areas of Greater Amazonia. Some phylogenetic studies of avian and mammalian genera have recovered Pliocene (5.3-2.6 Ma) divergence times among deeper branches, leading to the hypothesis that these events were associated with, or even caused by, the onset of the transcontinental Amazon River in the last 2.5 My (e.g. Ribas et al., 2012; Sousa-Neves et al., 2013; Fernandes et al., 2014; Alfaro et al., 2015). Studies on other taxa (fishes, amphibians, some birds, plants) have recovered late Miocene (10-5 Ma) dates for divergences among clades that inhabit multiple sedimentary basins of Amazonia (e.g. Antonelli et al., 2009, 2010; Santos et al., 2009; Albert et al., 2011a; Tagliacollo et al., 2015; Carneiro et al., 2018).

This paper has three main goals. The first is to explicate the role of sedimentary basins, bounded by uplands and structural arches, as fundamental geological units constraining the evolution of river basins in NSA through the Neogene. The second goal is to describe the spatial and temporal dimensions of a multi-stage model for the origin of the modern transcontinental Amazon River (sensu Figueiredo et al., 2009; Hoorn et al., 2017). The third goal is to describe the formation of mega-wetland landscapes in Greater Amazonia, a series of seasonally flooded várzeas and savannas that extend over more than one million square kilometers across tropical NSA (Miguez-Macho, Fan, 2012). The results support a pluralist approach to the study of basin and landscape evolution, in which multiple processes contribute to the formation of continental-scale river basins (Potter, 1978; Goudie, 2005; Potter, Hamblin, 2006; Hoorn et al., 2017; van Soelen et al., 2017), and the evolutionary diversification of riverine-associated taxa at continental scales (Santos et al., 2009; Albert et al., 2011a, 2017; Ribas et al., 2018).

Geological setting of Northern South America. "Although most of the stocks passed through periods in which they inhabited the eastern highlands, it was not until the Amazon developed its great freshwater basin that it became the greatest hatchery of species known (Eigenmann, Allen, 1942: 62)."

This section provides a brief primer of key terms, concepts, and geological features used in studies on the geomorphology and geology of the Amazon basin. Readers familiar with these issues may wish to skip ahead to the next section.

The principal landforms controlling the evolution of rivers in NSA are the upland Guiana and Brazilian Shields, the Andes, and a set of structural arches and sedimentary depositional basins, all of heterogeneous geological origins (Fig. 3). Many of these geological features have been known since the early $20^{\text {th }}$ Century (Schuchert, 1906; Branner, 1919), and some have been documented and characterized only in recent years.

The Guiana and Brazilian Shields, referred to collectively by Carl Eigenmann as the "eastern highlands", form, respectively, the northern and southern margins of Central 


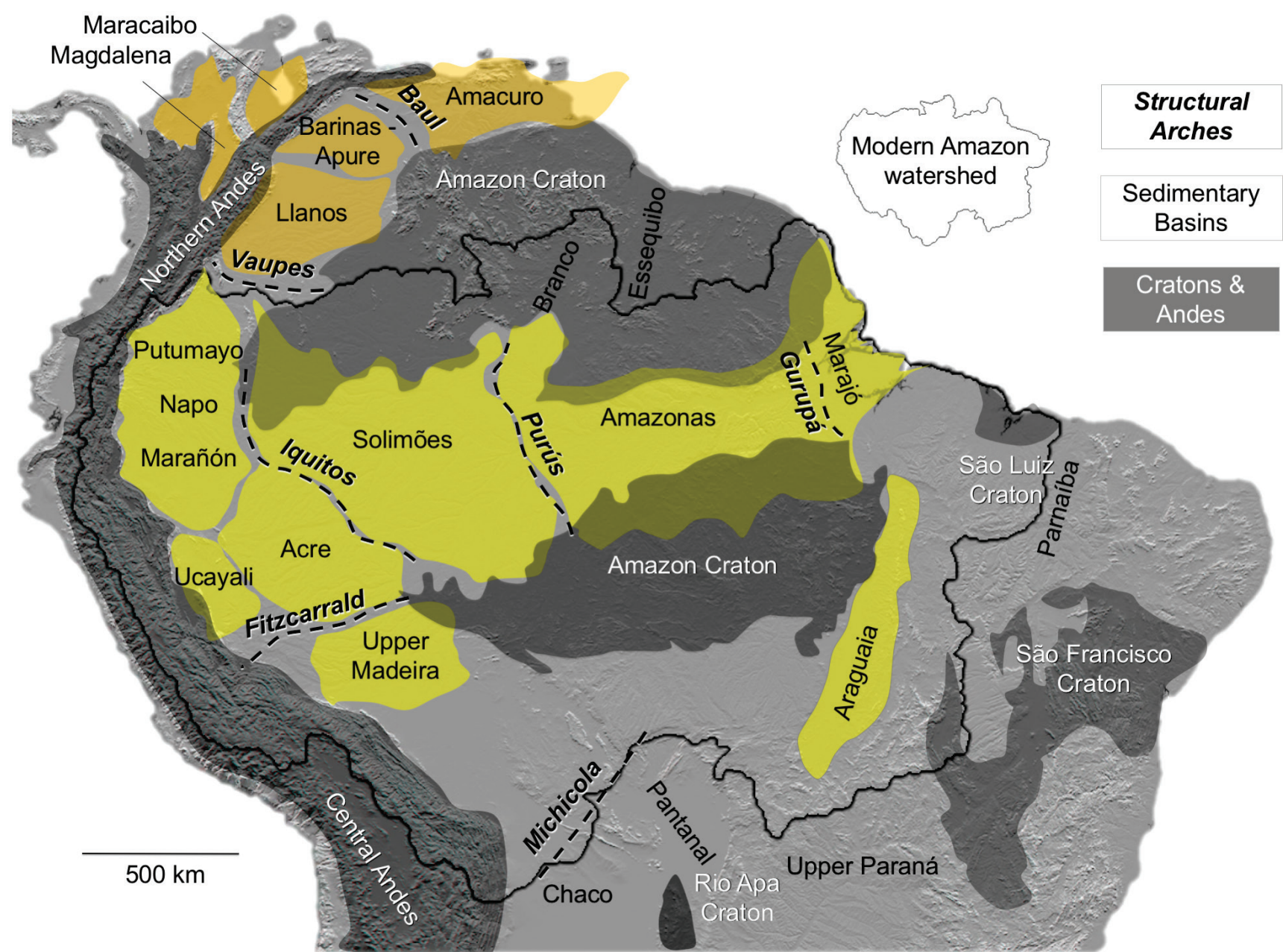

Fig. 3. Principle landforms controlling basin connectivity in northern South America. Structural arches (dashed lines) of diverse geological origins partially bounding sedimentary basins. Sedimentary basins in orange draining to the Caribbean; in yellow to the Atlantic. Structural arches and sedimentary basins from Costa Menegazzo et al. (2016) and Jaramillo et al. (2017). Note the Guiana Shield is composed mostly of the northern Amazon Craton, the Brazilian Shield by the southern Amazon craton, and the Atlantic Shield by the São Luís, São Francisco, Luís Alves and Río de la Plata cratons, all overlaid in parts with Paleozoic sedimentary formations.

and Eastern Amazon drainage basin in Brazil. These shields are now known to be composed of Proterozoic (2,500-541 Ma) crystalline igneous and metamorphic rocks that form the Amazon craton, along with some overlying Paleozoic (541-252 Ma) sedimentary formations (Hartmann, 2002). Together the shield regions occupy a total of $\sim 4.1$ million $\mathrm{km}^{2}$, or about $46 \%$ of the total area of NSA.

The much younger Andes orogenic belt extends along the western margin of the continent as a series of parallel and transverse ranges (cordilleras), plateaus and depressions. The Andes formed during the Late Cretaceous and Cenozoic (100-0 Ma) by compression and mountain building along the western margin of South America (Barckhausen et al., 2008; Horton, 2017). Subduction on the western South American margin drove a transition from an extensional tectonic regime associated with a westward (Pacific) draining pre-Andean landscape, to a compressive regime with an eastward (Atlantic) draining landscape during the Late
Cretaceous and Paleogene (Louterbach et al., 2018). The highlands of the Northern and Central Andes occupy an area of $\sim 1.6$ million $\mathrm{km}^{2}$, or about $18 \%$ the area of NSA.

The remaining $\sim 3.3$ million $\mathrm{km}^{2}$ or about $36 \%$ of NSA are lowland sedimentary basins, generally below about 250-300 $\mathrm{m}$ elevation. These lowland basins are drained by thousands of kilometers of large and deep ( $>5 \mathrm{~m}$ mid-channel depth) rivers meandering and anastomosing across broad sunlit floodplains, and tens of thousands of kilometers of non-floodplain (terra firme) streams and rivers, many flowing mostly under a closed-forest canopy (Toivonen et al., 2007; Crampton, 2011).

Many faces of the Amazon. The term Amazon describes several different and overlapping hydrological, geological, biological, and political entities. To avoid confusion, it is useful to distinguish the use of the term Amazon as the name of a drainage basin, river, biodiversity province, and ecoregion. The Amazon drainage basin is a watershed circumscribing 
more than 7.05 million $\mathrm{km}^{2}$ (including the Tocantins-Araguaia drainage basins), collecting waters from across $40 \%$ of the entire continental surface of South America, or about 5.2\% the surface area of all river basins on Earth combined (Lehner et al., 2008). This immense catchment is the most expansive drainage basin documented, and given that the continents are today larger than in previous eras (Hawkesworth et al., 2013), the Amazon drainage may be among the greatest ever assembled in Earth history (Albert et al., 2018). The Amazon drainage more-completely dominates South America than any other river basin on the planet, having accrued more than $42 \%$ of the total continental river-space, as compared with, for example, $24 \%$ by the Mississippi, $14 \%$ by the Yangtze, or $12 \%$ by the Congo drainages (Lehner et al., 2008).

Drawing water from this tremendous area, the Amazon River has the greatest annual flow on Earth, discharging an average of about $219,000 \mathrm{~m}^{3} \mathrm{~s}^{-1}$ or $20 \%$ of the world's total river water delivered to the sea, an amount greater than the next nine largest rivers of the world combined (Nittrouer, DeMaster, 1986; Milliman, 2001). The Amazon River also contains the largest surface area of wetlands (c. 250,000 $\mathrm{km}^{2}$ ), seasonally-inundated floodplains, savannahs, inland estuaries, and forests that may be flooded for many months of the annual cycle (Goulding et al., 2003; Gupta, 2007; Jongman et al., 2008; Melak, Hess, 2010). The use of the term Amazon as a drainage and river must not be confused with the Amazon sedimentary basin, a geological depression of about $620,000 \mathrm{~km}^{2}$ that lies between the Brazilian and Guiana Shields, and between the Purús and Gurupá structural arches (described in more detail below).

The Amazon drainage basin collects waters from across much of Greater Amazonia, a vast and ecologically heterogeneous biodiversity province, including alpine streams and torrential rivers of the Northern and Central Andes, moist lowland rainforests and seasonally-inundated floodplains, and seasonally-burned savannahs of the Guiana and Brazilian uplands shields. The margins of Greater Amazonia broadly coincide with that of the Amazon Rainforest ecoregion, the largest contiguous region of moist, tropical forests on Earth. This ecoregion covers about 5,500,000 $\mathrm{km}^{2}$ in nine countries, including most of lowland Amazonia, but excluding non-forested ecoregions of the Llanos in the Orinoco drainage, and the upper reaches of major rivers in the Brazilian Shield (e.g. Upper Madeira, Tapajos, Xingu, Tocantins).

The term Amazon is also used in the official names of states or departments in four nations; Brazil $\left(1,570,745 \mathrm{~km}^{2}\right)$, Colombia $\left(109,665 \mathrm{~km}^{2}\right)$, Peru $\left(39,249 \mathrm{~km}^{2}\right)$, and Venezuela $\left(183,50 \mathrm{~km}^{2}\right)$. In units of political geography, a majority of the Amazon drainage basin lies in Brazil $\left(4,756,680 \mathrm{~km}^{2}\right.$ or $\left.67 \%\right)$, with large areas also in Bolivia $\left(836,628 \mathrm{~km}^{2}\right.$ or $\left.12 \%\right)$, Colombia $\left(610,265 \mathrm{~km}^{2}\right.$ or $\left.9 \%\right)$, Ecuador $\left(92,000 \mathrm{~km}^{2}\right.$ or $\left.1 \%\right)$, Peru $\left(549,522 \mathrm{~km}^{2}\right.$ or $\left.8 \%\right)$, and Venezuela $\left(183,500 \mathrm{~km}^{2}\right.$ or $\left.3 \%\right)$.

Rivers, basins and arches. In describing the evolution of drainage networks, geomorphologists distinguish between several distinct uses of the term "basin" (Einsele, 1992;
Monroe, Wicander, 1997; Lambert, 1998). A "drainage basin", also called catchment or watershed, is a hydrological term for a land surface area in which all precipitation is contained within the watershed domain, either evaporating (or evapotranspiring), infiltrating into soil, and/or flowing to streams and eventually reaching the main stem. By contrast, a "structural basin" is a geological term for a large-scale topographic depression formed by tectonic deformation. Many structural basins are also "sedimentary basins", regions of the Earth surface with long-term subsidence and/or large accommodation space, where sediments accumulate and are preserved over geological time periods. Subsidence in turn often results from flexure of the crust due to topographic (caused by tectonics) or sedimentary (caused by erosion of uplifting highlands) loading (e.g. Jordan, 1981), but can also result from other processes as well, such as a downward, cold mantle flow underneath the Earth's crust (e.g. Forte et al., 1993). These processes act over different spatial and temporal scales and lead to distinct basin architectures. Active tectonics (i.e. plate collision), flexure, mantle flow, and intraplate faulting are all processes that cause or caused subsidence in different locations in the Amazon region and controlled the formation of its major sedimentary basins (e.g. Shephard et al., 2010; Wanderley-Filho et al., 2010; Eakin et al., 2014; Sacek, 2014; Caputo, Soares, 2016).

From a biogeographic perspective, a river may usefully be perceived as a whole drainage basin (e.g. Abell et al., 2008; Dagosta, de Pinna, 2017; Tedesco et al., 2017). The English word "river" (and cognates in many Indo-European languages, including the Spanish "rio" and Portuguese "rio") derive from Latin "ripa" for "bank", indicating that a river is defined by its banks. However, insightful observers have emphasized the fluid nature of rivers; e.g. panta rhei or "everything flows" by Heraclites of Ephesus (Robinson, 1987). The modern conception of a river includes waterways with multiple channels, those with intermittent or ephemeral flow, bankless waterways like the Florida Everglades or Pantanal Matogrossense, and the baseflow of groundwater from the watershed or catchment watertable (Ritter et al., 1995; Wiens, 2002; Pimentel, Hamza, 2012). The river channel contains only the subaerial portion of the total basin discharge. Channel flow contributes substantially to the total erosion of a continental hydrological system (Willenbring et al., 2013) and strongly affects important features of aquatic habitats like channel and floodplain morphology in the Amazon basin (Crampton, 2011). However, the sub-flow of groundwater contributes substantially to basin-wide erosion, in particular to headwater erosion, and therefore to the movement of watershed boundaries (Schaller, Fan, 2009; Miguez-Macho, Fan, 2012).

From a geomorphological perspective, a drainage system develops from a hierarchy of water flux processes occurring over a range of spatial and temporal scales, under particular geographic settings and particular climatic regimes (Goudie, 2005; Conti, 2012). Fluvial and erosional processes range from local hydraulic and sediment movement processes of 
channels operating over daily or annual time scales, to basin-scale processes associated with regional geological and global climatological contexts operating over millions of years. All the sediment stored in basins ultimately derives from a parent rock source. Fluvial erosion of the highlands (i.e. Andes and, to a lower extent, cratons) operating over millennia in response to regional geological processes (i.e. uplift of the Andes) is responsible for most of the sediment being transported and deposited downstream. Once caught in the fluvial system, sediments in large basins such as the Amazon may undergo several cycles of transportation and burial until reaching its ultimate "sink", the ocean basin (e.g. Wittmann et al., 2011).

It is not possible to describe the geologic setting of the sedimentary basins in Amazonia without describing their bounding structures, the structural arches. A "structural arch" or swell is a surface or sub- surface high or positive feature caused by relative uplift over an elongated region. The main structural arches in the Amazon drainage region are the Iquitos (or Envira), Purús, and Gurupá arches (Horbe et al., 2013). It is often observed that hard basement rock (or sometimes consolidated sediments) form parts of the boundary between adjacent sedimentary depositional basins (Wanderley-Filho et al., 2010). Such inter-basin arches may form under the influence of several different geological processes. Localized uplift may arise from tectonic subduction (e.g. Fitzcarrald and Vaupés Arches), oroclinal bending (e.g. Michicola Arch), forearc bulges (e.g. El Baul and Iquitos Arches), or strike-slip faults (e.g. Gurupá Arch). Structural arches can be reflected in the surface topography if there is differential subsidence and sediment deposition along adjacent fault zones (e.g. Michicola Arches). When expressed in the surface topography, structural arches form topographic barriers to drainage basins.

The Purús Arch is the portion of the Ventuari-Tapajos igneous belt that is today entirely buried under Neogene sediments of the modern transcontinental Amazon River (see fig. 1 in Bahlburg et al., 2009). The Ventuari-Tapajos belt is the one of four NW/SE trending geochronological provinces of Proterozoic origin that constitute the Amazon Craton, the belts decreasing in age from northeast to southwest (Cordani, Sato, 1999). The Ventuari-Tapajos belt formed during the Paleoproterozoic (c. 2.0-1.82 Ga) as igneous granitoids in a continental arc margin setting (Payolla et al., 2002). Given its great age, the Purús Arch has undergone a complex geological history (Wanderley-Filho, 1991; Bahlburg et al., 2009; Johansson, 2009; Caputo et al., 2016; Merdith et al., 2017). The Purús Arch originally formed as an inverted graben by NW-SE compression of the Amazon Craton during the Neoproterozoic (c. 1000-541 Ma), became exposed as a persistent structural high until the Pennsylvanian (c. 300 $\mathrm{Ma})$, underwent multiple episodes of subsidence and uplift during the Permian, Triassic and Jurassic (c. 300-145 Ma), was again a sustained topographic high throughout the Cretaceous and most of the Cenozoic (c. 145-10 Ma), and became buried by Andean-derived sediments with the onset of the modern transcontinental Amazon River.

Using the terms as defined above, we can better understand the geological setting of Northern South America (Fig. 1). The Amazon basin is not a rift valley, or even a single geological depression. Rather, the Amazon drainage basin is composed of four larger, and several smaller, structural basins, each encompassing one or more geologically distinct sedimentary basins, and all separated from one another by structural arches. The main axis of the Amazon River drains a series of sedimentary basins that formed over a protracted interval during much of the Phanerozoic (541-0 Ma). Most of these sedimentary basins formed in association with tectonic rifting of the South American and Africa plates during the Lower Cretaceous (145-100 Ma), and all these sedimentary basins were affected by uplift of the northern Andes during the Paleogene and Neogene. Broadly speaking, patterns of sediment dispersal and accumulation, and drainage reorganization in NSA reflect landscape evolution associated with protracted subduction of the Farallon, Nazca, and Cocos Plates (Horton, 2017). The underlying geological mechanisms can be traced to tectonic uplifts of the Northern Andes that occurred in several distinct orogenic phases, called the Incaic (48-34 Ma), Quechua 1 (17-15 Ma), Quechua 2 (9-8 Ma), and Quechua 3 (7-5 Ma) Phases (Gregory-Wodzicki, 2000; Pfiffner, Gonzalez, 2013; Bermúdez et al., 2015; Chiarabba et al., 2016; Horton, 2017).

The Western Amazon region encompasses several sub-Andean sedimentary basins (e.g. Acre, Marañon), while the Solimões, Amazonas, and Marajó sedimentary basins are intracratonic basins. Andean-derived fluvial sediments are recorded in the sub-Andean foreland from at least the early Paleocene or Eocene (Hurtado et al., 2018). The Western Amazon also separated from the Llanos basin to the north by the Vaupés Arch, and from the Upper Madeira basin in the south by the Fitzcarrald Arch. The Solimões and Amazonas basins are bounded to the north and south by portions of the Amazon Craton, represented as Guiana Shield to the north and Central Brazilian (or Guaporé Shield) to the south.

Recent studies emphasize the complex and diachronous (time-varying) uplift and deformation history of the northern Andes among its several parallel cordilleras and along its latitudinal extent (Garzione et al., 2017). While orogenesis (mountain building) is the underlying process that leads to massive erosion and sedimentation in the adjacent basins, later sediment redistribution and landscape changes might have been at least partly controlled by mantle-convection processes affecting the South American plate (Shephard et al., 2010), flat slab subduction (Eakin et al., 2014), and progressive eastward sediment-load driven flexure of the lithosphere (Sacek 2014).

Palaeodrainage history of NSA. "The key to the long-term survival of a large river is location on a long-lived craton or passive margin and persistence of continental tilt, all without interruption by desertification, continental glaciation or volcanism (Potter, Hamblin, 2006: 1).” 
Here we present a model of palaeodrainage evolution among the sedimentary basins of NSA, based on geochronological data obtained from multiple data types and sources (Sternberg, 1950; Potter, 1997; Lundberg et al., 1998; Costa et al., 2001; Hoorn et al., 2010a, 2017; Roddaz et al., 2010; Horton et al., 2015a; 2015b; Anderson et al., 2016; Horton, 2017; van Soelen et al., 2017; Hurtado et al., 2018). This model describing the origin of the modern Amazon and adjacent river basins has only come into focus in the past several decades (Hoorn et al., 1995; Díaz de Gamero, 1996; Lundberg et al., 1998; Hoorn et al., 2010a, 2017). Although we do not have space here to summarize all the alternative models proposed in the literature regarding the timing and configuration of these events, citations relevant to this literature are provided in Tab. 1. The data summarized in this paper are consistent with many but not all of these models.

Early studies from terrestrial sources based primarily on stratigraphic, structural mapping and macrofossil data (e.g. Frailey et al., 1988; Campbell et al., 2001) estimated Pliocene dates for the onset of the modern transcontinental Amazon (Tab. 1). By contrast, studies using isotopes and sediment geochemistry obtained from marine sediments off the coast of NE Brazil, early (e.g. Dobson, 1997, 2001) and consistently (e.g. Figueiredo et al., 2009, 2010; Gorini et al., 2014) estimated late Miocene dates. More recent studies combining data from multiple data types (including terres- trial pollen and marine plankton fossils, mass spectrometry, electron paramagnetic resonance spectroscopy) and regions (terrestrial and marine) have concluded late Miocene dates for the origin of the modern Amazon drainage regime (Caputo, Soares, 2016; Hoorn et al., 2017; Jaramillo et al., 2017; van Soelen et al., 2017; Allard et al., 2018; Lammertsma et al., 2018).

Studies based on the optically stimulated luminescence (OSL) dating method have reported Pleistocene (2.6-0.01 Ma) dates for the onset of transcontinentalization (Rossetti et al., 2015; Cremon et al., 2016). In our view, interpreting these dates, orders of magnitude younger than dates obtained using other methods, is clouded by several concerns. OSL measures a luminescence signal trapped in a crystalline lattice due to ambient radiation (i.e. the surrounding sediments) as an estimate of the amount of time an object has been shielded from sunlight. The technique was originally developed to date ceramics and other objects with crystalline structures (bones, shells) from archeological sites, and is competent for objects up to several hundreds of thousands of years old, beyond which the signal becomes saturated (Murray, Olley, 2002; Rhodes, 2011; Roberts et al., 2015; Wintle, Adamiec, 2017).

These Pleistocene dates estimated from OSL studies of Amazonian sediments are enigmatic. These dates may derive in part from quartz crystals that were exhumed at superficial incisions of a deeper sedimentary pile, as incision dates

Tab. 1. Summary of literature age estimates for onset of transcontinental Amazon river. Studies arranged by descending order of estimated mega-river capture date. Data types: Geophysics includes data from fission track (FT), radiometric (RM), stable isotopes (SI), and optical luminescence (OL). Sedimentology includes sediment provenance from stratigraphy, lithology, and chemistry (ST), structural mapping (SM), sonic or seismic logging (SL), and sedimentation or subsidence rates (SR). Biostratigraphy includes planktonic microfossils (PM), pollen (PO), and macrofossils (MF). Regions: Ama, Amazonas basin; Atl, Atlantic (Amazon fan, Ceará rise); Lla, Llanos basin; NSA, Northern South America; Sol, Solimões basin; Wam, Western Amazon basins. Data sources are terrestrial (Ter) or marine (Mar).

\begin{tabular}{|c|c|c|c|c|c|c|c|}
\hline \multirow{2}{*}{ Epoch } & \multirow{2}{*}{$\begin{array}{c}\text { Dates } \\
(\mathrm{Ma})\end{array}$} & \multirow{2}{*}{ Reference } & \multicolumn{3}{|c|}{ Data type(s) } & \multirow{2}{*}{ Region(s) } & \multirow{2}{*}{ Source(s) } \\
\hline & & & Geochronology & Sedimentol. & Biostrat. & & \\
\hline \multirow[t]{9}{*}{ Upper Miocene } & 12.6 & Jaramillo et al., 2017 & SI (13C) & $\mathrm{ST}, \mathrm{SL}$ & $\mathrm{PM}, \mathrm{PO}, \mathrm{MF}$ & Lla, Wam & Mar. \& Ter. \\
\hline & $11.6-11.2$ & Heinrich, Zonneveld, 2013 & & ST, SR & PM & Atl & Mar. \\
\hline & 10.5 & Figueiredo et al., 2010 & RM, SI (Sm-Nd) & ST, SL & PM & Atl & Mar. \\
\hline & 10.1 & Caputo, Soares, 2016 & $\mathrm{ST}^{*}, \mathrm{SL}^{*}, \mathrm{SI}^{*}(\mathrm{U}-\mathrm{Pb})$ & $\mathrm{ST}^{*}, \mathrm{SM}^{*}$ & & NSA & Mar. \& Ter. \\
\hline & 10.1 & Mora et al., 2010 & $\mathrm{FT}^{*}, \mathrm{RM}^{*}, \mathrm{SL}^{*}$ & $\mathrm{ST}^{*}, \mathrm{SM}^{*}$ & $\mathrm{PO}^{*}$ & Wam & Ter. \\
\hline & $9.0-10.0$ & Dobson et al., 1997; 2001 & & ST & & Atl & Mar. \\
\hline & $9.5-8.3$ & Gorini et al., 2014 & $\mathrm{RM}, \mathrm{SL}$ & ST & PM & Atl & Mar. \\
\hline & $9.0-9.4$ & Hoorn et al., 2017 & SL & SI & $\mathrm{PO}$ & Atl & Mar. \\
\hline & 8.7 & van Soelen et al., 2017 & SI (13C, Sm-Nd) & ST & & Atl & Mar. \\
\hline Pliocene & $5.3-3.6$ & Latrubesse et al., 2010 & & ST, SM & MF & Wam, Sol & Ter. \\
\hline \multirow{2}{*}{ Pleistocene } & $<0.78$ & Rossetti et al., 2015 & $\mathrm{OL}$ & ST & & Sol, Ama & \\
\hline & 0.019 & Cremon et al., 2016 & OL SI (14C) & ST & & Sol, Ama & \\
\hline Total & & 16 & 11 & 16 & 12 & 16 & 13 \\
\hline
\end{tabular}


older than the maximum OSL range are not recordable. In other words, a likely reason for these young OSL ages in Amazonia is that the sediments are slowly being recycled. As a further complication, sediments in most Amazonian sedimentary formations are likely to be of heterogeneous ages, as sediments are buried, exhumed, re-deposited downstream and buried again. For instance, the Içá Formation may include Andean sediments from a megafan that extended far into the Solimões basin (Latrubesse et al., 2010; Wilkinson et al., 2010; Horbe et al., 2013). Such megafans are likely to have formed during pluvial (interglacial) cycles and sea level high-stands, while glacial incision during glacial cycles would have cut deep into floodplains, producing much of the sediment deposition downstream and at modern Amazon Fan (Irion, Kalliola, 2010). Pleistocene dates may therefore record, at least in part, fluvial dynamics during Pleistocene climatic cycles, and do not necessarily contradict a late Miocene age estimate for the onset of a transcontinental river.
A two-stage river capture model. The data reviewed here allow us to recognize at least two stages in the transformation of NSA from a predominately north-draining, to a predominately east-draining, palaeodrainage configuration (Fig. 4). Throughout most of the Late Cretaceous and Paleogene, most rivers in the western portion of NSA drained into the north-trending sub-Andean foreland (orange regions in Figs. 3 and 4), and from there into the proto-Caribbean Sea. These rivers drained basins that today lie to the west of the modern northern Andes (i.e. the trans-Andean Magdalena and Maracaibo basins; Aguilera et al., 2013; Pérez-Consuegra et al., 2018), as well as cis-Andean Western Amazon and Solimões basins with headwaters reaching to the Purús and Michicola Arches. Rivers in the eastern portion of NSA drained to the Atlantic Ocean (yellow regions in Figs. 3 and 4). As described above, the Purús Arch has been hypothesized to form part of the western margin of the sub-Andean foreland before the middle Miocene (Courtillot et al., 2003;

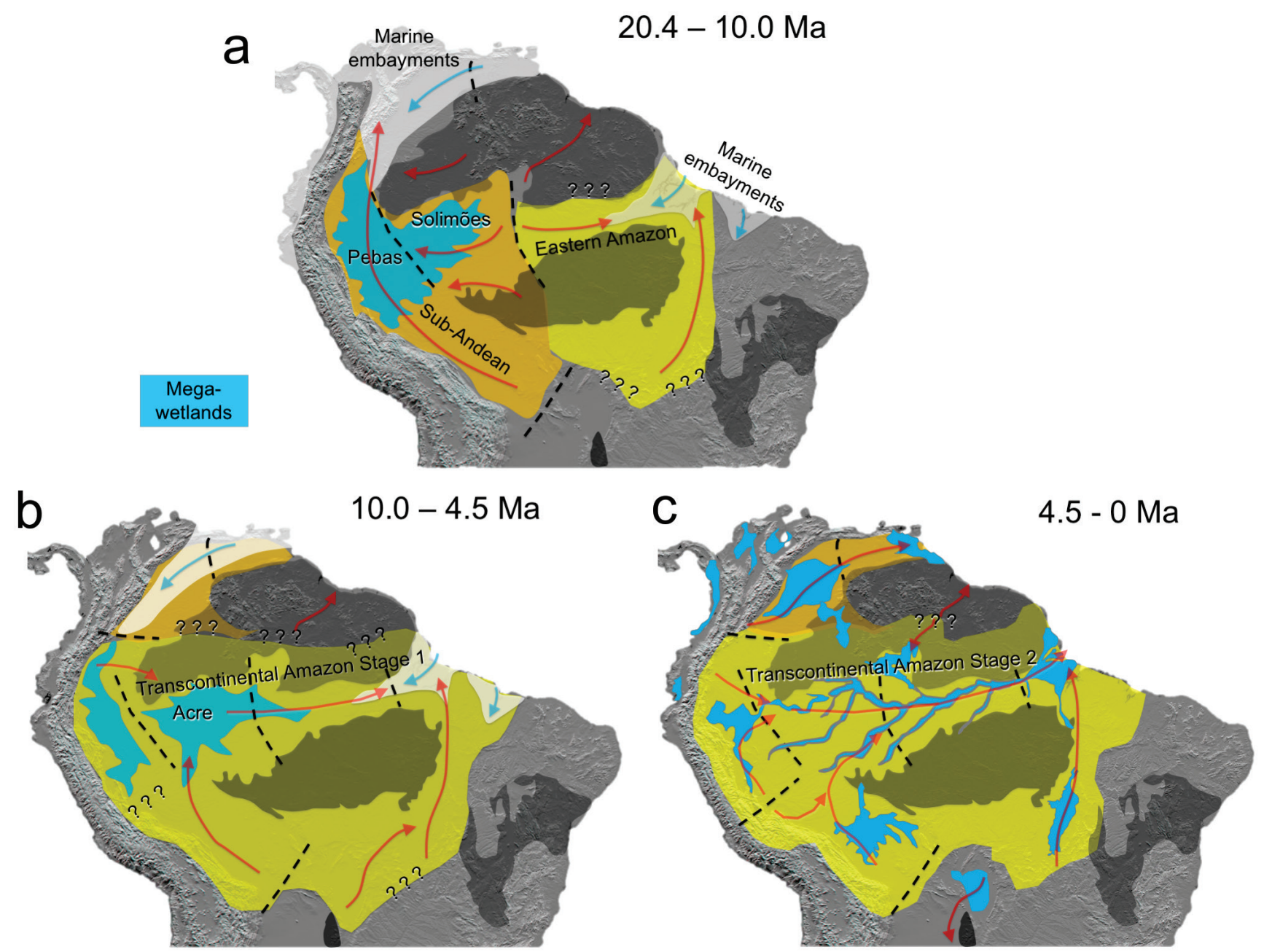

Fig. 4. The changing courses of rivers in northern South America through the Neogene. Reconstructions based on paleogeographic history of major sedimentary basins. a. Early and Middle Miocene (20.4-9.0 Ma). North-trending Sub-Andean river basin orange; east-trending Eastern Amazon river basin yellow. b. Late Miocene (9.0-5.3 Ma). East-trending transcontinental Amazon river basin (Stage 1). c. Middle Pliocene - Recent (c. 4.5-0 Ma). East-trending transcontinental Amazon river (Stage 2). 
Caputo et al., 2016; Hurtado et al., 2018). The Eastern Amazon drainage received discharge from some south-trending rivers of the eastern Guiana Shield (e.g. proto-Trombetas river) and north-trending rivers of the eastern Brazilian Shield (e.g. proto-Tocantins-Araguaia, proto-Tapajos, and proto-Xingu rivers). The watershed boundaries of these northern and southern tributaries of the Eastern Amazon River basin are as-yet poorly delimited, and these boundaries are denoted with question-marks in Fig. 4.

Transcontinental Amazon Stage 1 occurred in the late Miocene (10.0-4.5 Ma), beginning with the first large flux of Andean-derived sediments arriving at the river mouth (van Soelen et al., 2017; Hoorn et al., 2017). Transcontinental Amazon Stage 1 therefore had at least some Andean headwaters, perhaps in the Central Andes at the southwestern margin of the Upper Madeira sedimentary basin, as well as headwaters reaching to the Michicola Arch and Serra da Bodoquena at the southern margin of the Paraguay sedimentary basin (De Alvarenga et al., 2009). The Neogene sedimentary record of the northern Andean basins is largely lacking large coastal deltas, such as the Misoa Formation (early-middle Eocene) of the Maracaibo basin (Aguilera et al., 2013). It is therefore possible that waters of the sub-Andean foreland did not usually flow through a single large river stem, but rather through numerous smaller rivers. The direction of magnitude of water flow from the Western Amazonian basins (e.g. Putumayo, Napo, Marañon) during are uncertain during this time, indicated by a dashed arrow in Fig. 4B. Available data indicate the rise of the Vaupes Arch around 10 Ma completely separated the Western Amazon and Llanos basins (Hoorn et al., 2010a, 2010b; Jaramillo et al., 2107). The watershed-divide of the Pebas and Acre mega-wetlands is also uncertain during this time, indicated by question marks in Fig. 4B.

Transcontinental Amazon Stage 2 occurred from about the middle Pliocene to Recent (4.5-0 Ma), with Western Amazonian basins discharging east to the Atlantic, and with Amazonian headwaters extending into the Northern Andes. Before c. 4.5 Ma, the Iquitos Arch blocked transport of Andean-derived sediments from the Western Amazon (i.e. the North Amazon Foreland Basin or NAFB of Horbe et al., 2013) to the Amazon Fan (van Soelen et al., 2017). This resulted in the accumulation of sediments known as the Nauta/Içá Formation. The greatest increase in total sedimentation rates throughout the basin occurred at the start of the Quaternary, c. 2.6 Ma (Figueiredo et al., 2009; Hoorn et al., 2017). Although the Iquitos arch served as a sediment trap during this interval, it did not prevent Andean-derived waters from flowing East through the Solimões and Amazonas sedimentary basins and discharging into the Atlantic. This sediment trap persists in part up the present in the Ucamara depression, serving as the substrate for the Pacaya-Samiria wetlands (Dumont, 1996).

The principal drivers of these changes in transcontinental drainage patterns were: increased Andean denudation and sediment delivery (Mora et al., 2010; Roddaz et al., 2010), river deflection by basement arches (Hoorn et al., 1995; Costa et al., 2001; Anderson et al., 2016), and mid-continental subsidence possibly driven by subducted slab dynamics (Eakin et al., 2014) and mantle convection (Shephard et al., 2010), and lithospheric responses to sediment loading (Sacek, 2014).

The paleogeographic reconstructions depicted in Fig. 4 have relatively low resolution through time and across space, due to the incomplete nature of currently available data. Uncertainties arise from insufficient stratigraphic age control, conflicting understanding of basin structural configurations, contrasting modes of sediment accommodation, unconformities (attesting to temporal gaps in the sedimentary record), stratigraphic intervals with unclear definitions, and deficient correlations of stratigraphic intervals across basins (Jaramillo et al., 2017).

Watershed migration. Watershed migration occurs due to differential erosion on either side of a catchment divide. In most applications, stream erosive power can be quantitatively described by river discharge and channel slope (Whipple, Tucker, 1999). Despite river discharge being an important parameter controlling the grain size transported by rivers (e.g. Lague et al., 2005) which in turn affects stream incision (Sklar, Dietrich, 2004), most of the variance of erosion rates observed globally can be explained by the river channel slope and hillslope gradient, rather than drainage area (e.g. Harel et al., 2016). This means that slope usually dominates, such that watersheds are predicted to migrate in the direction of the steeper slope (e.g. Gasparini et al., 2007; Whipple et al., 2017). In the Guianas, the prediction is that north-draining Atlantic basins (e.g. Essequibo) should capture adjacent Amazon headwaters (e.g. Branco). However, the empirical situation seems to be the reverse across this watershed, and others (e.g. Casiquiare canal; Stokes et al., 2018). There are also other factors that may affect the direction of watershed migration, including local heterogeneities in sediment/bedrock density, precipitation, subsurface flow, and tectonic uplift. Scale is important in assessing the relative contributions of these factors, which may dominate at different baselines/wavelengths; e.g. local (10 km) vs. regional $(1,000 \mathrm{~km})$.

Changing patterns of connectivity among NSA drainage basins through the Neogene produced several large-scale trends in the direction of watershed migrations, with predictable consequences for biogeography and biodiversity. Each basin-capture was a geodispersal event; e.g. the merging of the Solimões and Amazonas basins by breaching of the Purús Arch c. 9.4 Ma. Geodispersal events are expected to have enriched the aggregate biota of the expanding Amazon drainage basin by increasing its total area, and also by allowing species to expand their geographic ranges along continuous river channel and floodplain habitat corridors extending between newly connected regions. Each basin capture was also a vicariance event; e.g. separation 
of the Solimões from the Llanos sedimentary basins across the Vaupes Arch at c. 9.4 Ma. Vicariance events are well known to promote speciation by subdividing species ranges across a newly-formed barrier (Nelson, Rosen, 1979; Wiley, 1988). A less-well appreciated consequence of vicariance is that they also promote extinction (Albert, Crampton, 2010; Albert et al., 2017), as populations with a reduced range and population sizes have higher risk of stochastic extirpation (Fagan, 2002).
Here we describe four large-scale trends in watershed migration associated with the formation of the modern Amazon drainage basin.

1. Expansion of Atlantic-draining basins, contributing to the formation of the transcontinental Amazon, at the expense of Caribbean-draining Andean foreland basins (Fig. 5).

2. Expansion of Amazon-draining headwaters at the expense of coastal-draining basins of the Western Guiana Shield (WGS). Evidence of these river captures is readily

\section{Lower \& Middle Miocene}

\section{Upper Miocene - Lower Pliocene}

\section{Plio-Pleistocene}

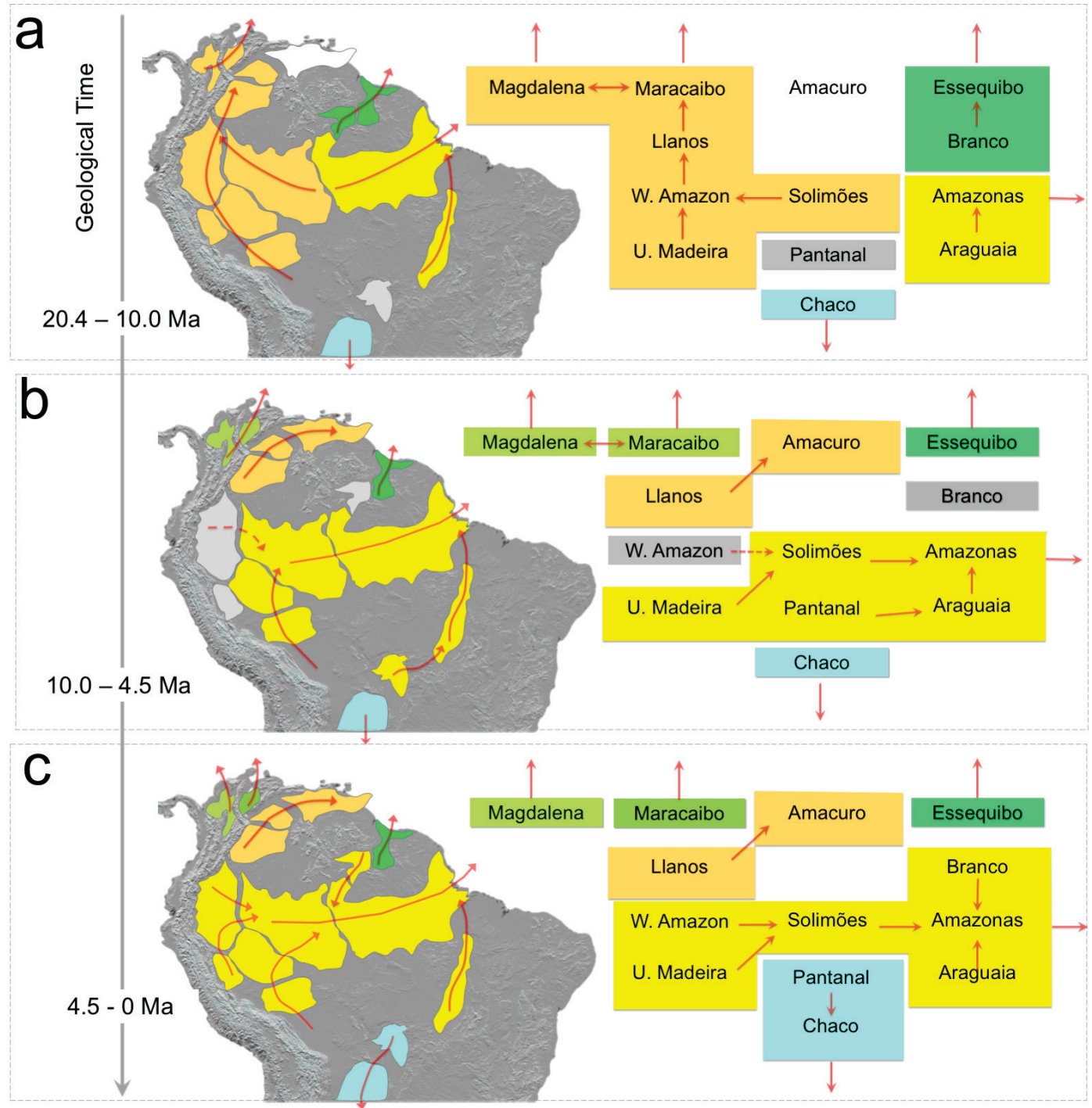

Fig. 5. Summary of hydrological connections among major sedimentary basins of northern South America through the Neogene. Caribbean-draining Andean foreland basins in orange. Atlantic-draining basins contributing to transcontinental Amazon in yellow. Other north Atlantic-draining basins in shades of green. South Atlantic-draining (La Plata) basins in blue. Connectivity as a block-design landscape evolution model at right preserving general spatial relationships. Red arrows depict predominant direction of sediment and water flow. Double-headed arrow indicates bidirectional connections during that time interval. Vicariance events when basins of the same color change to different colors between time intervals; geodispersal events when basins with different colors change to same color. Connections of basins in grey are poorly constrained by available data. Basin in white is entirely marine. "W. Amazon" refers to the combined Putumayo, Napo, Marañón and Ucayali sedimentary basins, "Llanos" to the combined Llanos, and Barinas/Apure basins, "Amazonas" to the combined Amazonas and Marajo basins, and "Essequibo" to the Proto-Berbice basin. Sedimentary basins with four letter abbreviations at left in top panel. Base-maps with modern coastlines and topography to facilitate orientation. 
observed in the many signature elbows, U-turns, rapids and waterfalls of the uppermost Negro and Branco basin headwaters (e.g. Casiquiare, Siapa, Mucajaí, Uraricoera, Takutu; e.g. Goldberg et al., 2017). These landforms indicate a landscape displaced from equilibrium, driven by tectonic event(s) or changes in relative base-levels, all serving to drive river captures (Renwick, 1992; Thorn, Welford, 1994; Kooi, Beaumont, 1996; Church, 2002; Ward et al., 2002; Black et al., 2017; Rodríguez-Tribaldos et al., 2017). These river captures resulted in geodispersal of coastal-basin headwaters to the Amazon, thereby enriching the Amazonian biota, and vicariances isolating sister species on either side of the WGS-Amazon divide.

3. Expansion of Amazon-draining headwaters at the expense of coastal-draining basins on southern (Brazilian) escarpment of the Eastern Guiana Shield (EGS). The river network in the EGS generally approximates a radial pattern, draining away from central uplands of the Tumuc-Humac ridges along the borders of Brazil, French Guiana and Suriname. There are relatively few obvious landforms resulting from river capture of the same magnitude as those depicted in Fig. 4, and much of the drainage network is controlled by tectonic fault lines (de Almeida et al., 2000). However, the rivers of the southern escarpment (e.g. Jarí, Paru, Nhamunda, Trombetas) all flow to the southeast, against the more general landscape gradient that rises towards the east. This lack of conformity between the local direction of river flow and the general tilt of the longer-wavelength topography also indicates a landscape far from erosional equilibrium, with multiple water gaps (i.e. putative river captures) across the E-W trending ridge forming the contact between the $\mathrm{Pa}$ leozoic sediments and the crystalline basement, and extending along the southern EGS margin at about $51.5^{\circ}-59^{\circ} \mathrm{W}$, $1^{\circ}-2^{\circ} \mathrm{S}$.

4. Amazonian headwaters on the Southern Brazilian Shield (SBS) have been lost to encroaching La Plata basins; in particular the Pantanal basin to the Paraguay drainage (Carvalho, Albert, 2011; Assine et al., 2015; Pupim et al., 2015). An interpretation is that the larger Amazon basin gains at the expense of neighbors when erosion dominates the equation for watershed migration, and that basin size is less important than local tectonic forcings near the Andes and especially near the Bolivian Orocline.

Mega-wetlands of Greater Amazonia. Large fluvio-lacustrine and seasonally-flooded wetlands with a similar biotic composition and habitat physiognomy are distributed across much of the modern tropical NSA (Miguez-Macho, Fan, 2012; Fig. 6). Such wetlands, extending over tens to hundreds of thousands of square kilometers, dominate landscapes of the lower Magdalena, Maracaibo, Llanos, Western Amazon (Marañón-Ucayali), middle Negro (Pantanal Septentrionalis), upper Negro (Roraima savanna), and upper Madeira (Llanos de Moxos) basins. In addition, the várzeas of the Amazon River floodplain represents about $2 \%$ of the total area of the Amazon drainage basin, or about $12 \%$ of all the Amazon basin wetlands. The modern várzeas, pantanals and seasonally flooded savannahs of NSA all exhibit similar faunal and floristic taxonomic composition (Godoy et al., 1999) and ecosystem phenology (Melack, Hess, 2010).

The large wetlands of modern NSA trace their origins to the geographic and climatic conditions of the Western Amazon during the early Neogene (Hoorn et al., 2010b; Hughes et al., 2013; Antoine et al., 2017; Fig. 7). In the early and middle Miocene, extensive areas of the Western Amazon were covered by mega-wetlands that served as the environment of deposition for the Pebas Formation as it is known in Peru, or the Solimões and Acre Formations as they are known in Brazil. The Pebas/Solimões/Acre Formation consists of fine-grained and cation-rich clay sediments deposited under lacustrine or lacustrine-fluvial conditions (Hoorn, 1993; Räsänen et al., 1995; Gross et al., 2011; Hoorn et al., 2010a; Hovikoski et al., 2010; Wesselingh, Hoorn, 2011). The formation of these early and middle Miocene mega-wetlands was associated with higher eustatic sea-levels of the Miocene climatic optimum (Jaramillo et al., 2017), and the Quechua 1 phase orogeny of Northern Andes (c. 17-15 Ma) that depressed the northern Andean foreland basin (Horton, 2017). Lying above these deposits are the Nauta Formation in Peru, or Içá Formation in Brazil. The Nauta/Içá Formation consists of coarse-grained and cation-poor fluvial or deltaic sediments deposited during the Pliocene to Pleistocene ( $c$. 4.5-0.1 Ma; Rossetti et al., 2015; Rebata et al., 2006; Wesselingh, Hoorn, 2011; Nogueira et al., 2013).

Mega-wetlands of central and western Amazonia differed in several important regards from the Miocene to the Pliocene. The Pebas/Solimões/Acre Formation is lacustrine-fluvial with a prominence of lacustrine deposits, and the Nauta/Içá Formation is fluvio-lacustrine with a with a prominence of fluvial (i.e. riverine) deposits. These differences in depositional environment are associated with a different biotic (i.e. taxonomic) composition and habitat physiognomy (Hoorn et al., 2010a; Jaramillo et al., 2010, 2017; Hoorn et al., 2017). As inferred from palynology, the plant species composition of the Plio-Pleistocene Nauta/Içá Formation and modern várzeas differ from that of the Miocene Solimões/Pebas Formation, indicating that characteristic plant composition along the Andes-Amazonian altitudinal gradient, and on the floodplains of the large lowland sediment-rich rivers of modern NSA (e.g. Junk, 1993; Wittmann, Junk, 2003; De Assis, Wittmann, 2011) first appeared in Pliocene (Wesselingh et al., 2001; Wesselingh, Salo, 2006; Hoorn et al., 2010b, 2017; Jaramillo et al., 2017).

Despite these important differences through time and across space, mega-wetland ecosystems have persisted, under different configurations and with differing species compositions, in Western Amazonia for $>15$ million years, from the early to middle Miocene right up to the present. In other words, for much of the time period since about the middle Miocene (15 Ma), mega-wetlands in one form or another have extended over an immense area of $>750,000 \mathrm{~km}^{2}$, or about $10 \%$ the total surface area of the modern Amazon ba- 

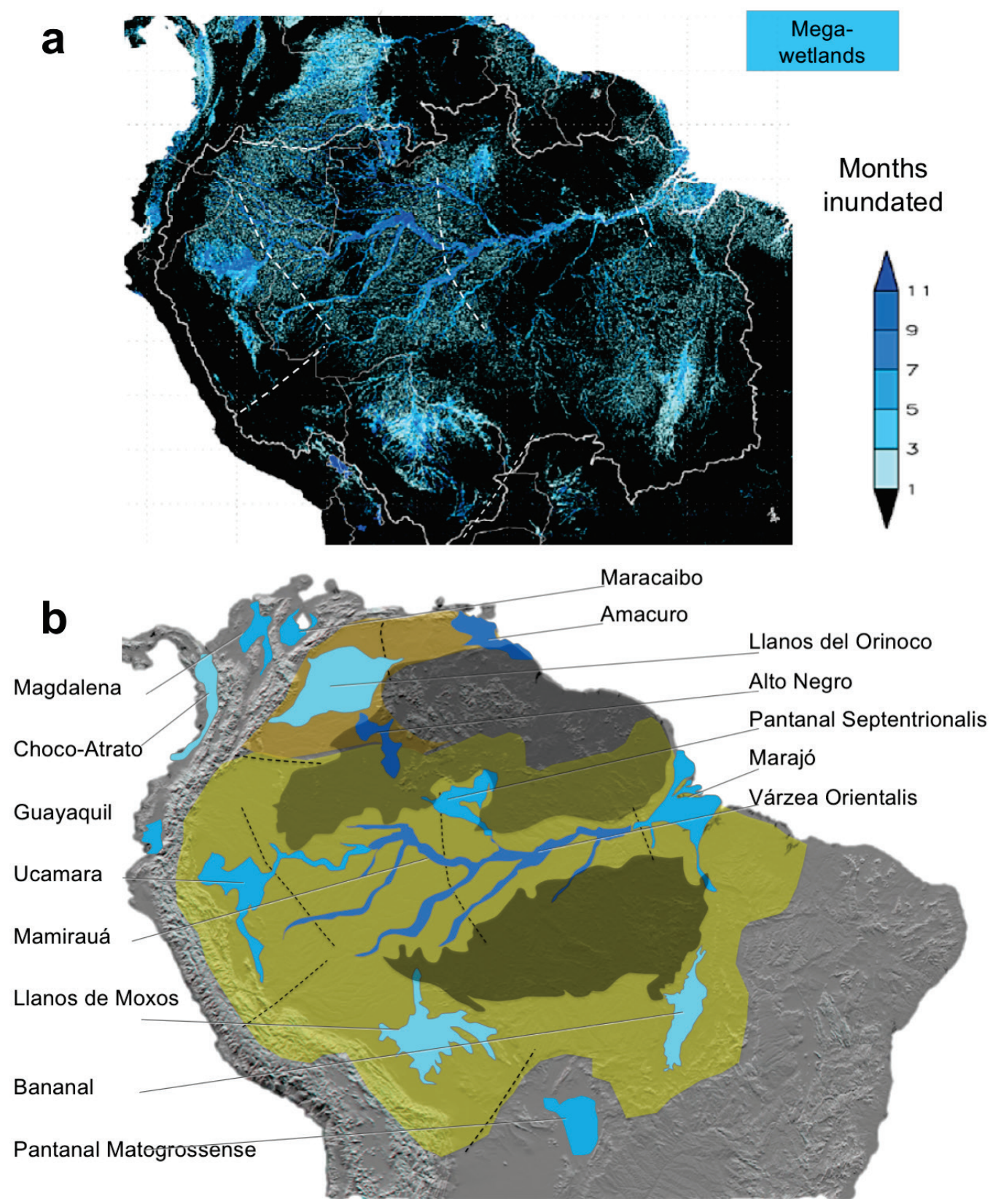

Fig. 6. Mega-wetland systems of modern tropical South America. a. Mean number of months of inundation (from Miguez-Macho, Fan, 2012). Simulated flooding frequency as number of months per year over the 10-year period, 2001-2010. b. Schematic depiction of 15 largest mega-wetlands $\left(>10,000 \mathrm{~km}^{2}\right)$; intensity of blue shading proportional to average annual duration of inundation. Cartographic conventions as in Fig. 3. Note highly fragmented distribution of mega-wetlands on the modern landscape, and localization of mega-wetlands towards center of larger sedimentary basins.

sin. Understanding the historical continuity of these paleo and modern mega-wetland ecosystems informs historical interpretations of biotic diversification advanced by recent papers, which assume a loss of mega-wetlands from the Miocene to the Recent (e.g. Moreno-Bernal, 2014; Martins et al., 2017; Pérez-Escobar et al., 2017).

Pronounced changes in geographic connectivity of mega-wetlands during this time interval, range from more connected in the late Miocene to more fragmented in the Pliocene to Recent (Fig. 6). Fragmentation of this habitat contributed to diversification in many freshwater fish taxa, including pimelodid catfishes (Tagliacollo et al., 2015) and apteronotid electric fishes (Evans et al., 2017b). Mega-river captures at the scale of sedimentary basins also allowed taxa originating in the Western Amazon to disperse into the Eastern Amazon, Essequibo, and Parana drainages (Albert et al., 2011a; Dias et al., 2014; Evans et al., 2017a), and isolated taxa in the trans-Andean, Llanos, and Upper Madeira regions (Albert et al., 2006; Albert et al., 2011a; Tagliacollo et al., 2015). 


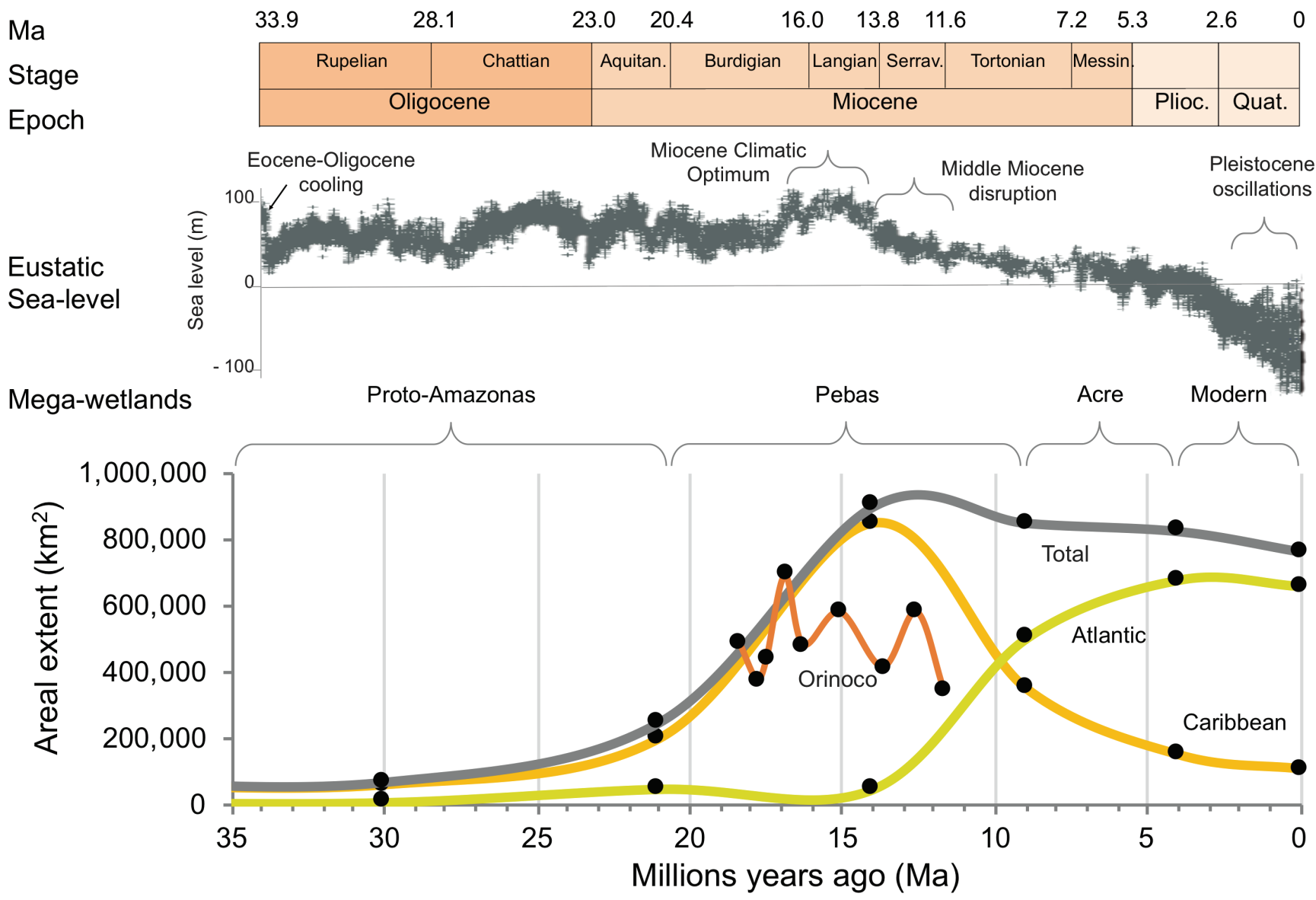

Fig. 7. Growth of mega-wetlands in northern South America. Geological time scale at top. Eustatic sea-level estimates from Zachos et al. (2001). Area estimates of for Atlantic and Caribbean draining mega-wetlands from paleogeographic reconstructions in Wesselingh, Hoorn (2010) and Hoorn et al. (2017), and for the Orinoco basin by Jaramillo et al. (2017). Caribbeandraining Andean foreland basins in orange; Atlantic-draining basins contributing to transcontinental Amazon in yellow. Areas estimated using ImageJ (Abràmoff et al., 2004). Curves smoothed using a third-order Bezier Spline.

\section{Conclusions}

"Rivers come to be what they are by slow processes of natural development, in which every peculiarity of river-course and valley-form has its appropriate cause (Davis, 1889: 2)."

The evolution of Amazonian drainage basins conformed with changes in the hydrological connections of NSA structural basins through time. These riverscapes evolved under the influences of geological and climatic processes operating over millions to billions of years. These processes include tectonic plate collisions driven by mantle convection resulting in subduction and orogenesis, in combination with lithospheric and surface processes such as fluvial erosion acting under constraints impose by regional and global climatological regimes (Potter, Hamblin, 2006; Hoorn et al., 2010a, 2017; Galloway et al., 2011).

Modern NSA drainage systems trace their origins to the Cretaceous breakup of Western Gondwana (Potter, 1997; Beard, 2003; Goudie, 2005). Prior to rifting, the predominant flow of drainages in the South American portion of Western
Gondwana was to the west, away from highlands located along the rift zone (Ribeiro et al., 2006; Mapes 2009; Hurtado et al., 2018). Rifting of the South American and African plates about 120-100 Ma changed drainage flows across NSA by the uplift of bounding mountains (e.g. Andes to the west, Guiana and Brazilian Shields to the east), and the subsidence of internal basins. Throughout the Upper Cretaceous and Paleogene (c. 100-23 Ma) the predominant direction of water flow across NSA was through two catchments; 1) a west-trending Solimões basin and north-trending sub-Andean foreland, together draining to the proto-Caribbean, and 2) an east-trending Amazonas basin draining to the Atlantic (Courtillot et al., 2003; Hurtado et al., 2018). The sub-Andean foreland of the Upper Cretaceous and Paleogene was the geographic location of, and the geological time frame for, the evolutionary origins of major clades of the Neotropical freshwater biota (Lundberg et al., 1998; Albert et al., 2011b; López-Fernández, Albert, 2011).

Oligocene-early Miocene (34-20 Ma) breakup of the Farallon plate into the Nazca and Cocos plates, and the subsequent collision between the Nazca and South American 
plates (Barckhausen et al., 2008), uplifted the cordilleras of the Northern Andes, and hydrologically isolated the modern trans-Andean Atrato, Magdalena, and Maracaibo drainages from the cis-Andean Amazon and Orinoco drainages (Albert et al., 2006; Aguilera et al., 2013; Bermúdez et al., 2015). Associated with this orogeny were the exhumation of the Vaupés Arch and sediment overfilling of portions of the sub-Andean foreland, both contributing to the breaching of the Purús Arch and formation of the modern transcontinental Amazon drainage (Horton, 2017). Pleistocene climate fluctuations seem to have had relatively little effect on the formation of regional-scale drainage patterns. Pleistocene shoreline changes may have produced reticulated patterns of connectivity among rivers draining coastal plains, for example along the coastal margins of the Guianas and Brazilian Shields (e.g. Thomaz et al., 2017).

Despite the many advances described above in understanding Amazonian geology in the past 20 years, important questions remain unanswered: How big was the sub-Andean drainage basin, and what was the size of the floodplains and river(s) of that basin as compared with those of the modern Amazon basin? Precisely where, when, and in what sequence, did the river captures occur resulting in the modern watersheds of the Araguaia-Paraná, Araguaia-Paraguay, Guaviare-Negro, Branco-Essequibo, Eastern Guianas, and Ucayali-Madeira (indicated with question marks in the paleogeographic reconstructions of Fig. 4)? What if anything was the nature of the hydrological separation between the Pebas and Acre paleobasins in the late Miocene?

The reconstructions of drainage-basin evolution presented here are obviously simplistic and course-grained, in both spatial and temporal dimensions. They are offered to the community as hypotheses to inspire the collection and analysis of new sedimentological and geochronological datasets. The patterns of drainage isolation and merging we propose here may be also compared against results of studies on the historical biogeography of taxa in which evolutionary diversification is thought to be tightly tied to riverscape geography. Future research will require better models and better empirical datasets on which to test those models.

The overall conclusions of this study have quite a different flavor from those of Smith et al. (2014), who claimed that landscape evolution is not a decisive factor in Neotropical diversification. It is beyond the scope of this study to link geographic changes in river connections to patterns of diversification in particular taxa. However, the paleogeographic model presented here is consistent with the notion that diversification rates may differ among taxa that exposed to the same landscape evolution events, depending on how lineages persist within, and how easily they may disperse among, geologically persistent sedimentary basins.

\section{Acknowledgments}

We thank Jose Birindelli, Carla Pavanelli and Luiz Malabarba for the invitation to contribute this paper to the sympo- sium volume, and the following colleagues for stimulating discussions on the connections between the evolution of life and land: Laurie Anderson, Alexandre Antonelli, Jon Armbruster, Maxwell Bernt, Kenneth Campbell, Tiago Carvalho, Prosanta Chakrabarty, Joel Cracraft, Jack Craig, William Crampton, Scott Duke-Sylvester, Kory Evans, William Fink, Lesley Kim, Gary Kinsland, Shannon Kuznar, Aaron Fronk, Roosevelt Garcia, Nicole Gasparini, Flávio Lima, Nathan Lujan, John Lundberg, Hernán López-Fernández, Nathan Lovejoy, Nathan Lyons, Luiz Malabarba, Thierry Oberdorff, Javier Maldonado-Ocampo, Paulo Petry, Mário de Pinna, Ying Reinfelder, Roberto Reis, Alexandre Ribeiro, Fábio Roxo, Isabel Sanmartín, Gerald Smith, Victor Tagliacollo, Pablo Tedesco, Andrea Thomaz, Hanna Tuomisto, Peter Van der Sleen, Brandon Waltz, David Webb, Ed Wiley and Jane Willenbring. Carlos Jaramillo, John Lundberg, Brian Sidlauskas and an anonymous reviewer provided detailed and helpful reviews of the manuscript. We also wish to acknowledge María Díaz de Gamero and John Lundberg for the wonderful allusions borrowed for the title of this paper. This work was supported by United States National Science Foundation DEB 0614334, 0741450, and 1354511 to JSA, GEO 1641243 to Jane K. Willenbring (support for PV), and the CAPES/Science Without Borders program (\#0515-12-4; Brazilian Government) to PV.

\section{References}

Abell R, Thieme ML, Revenga C, Bryer M, Kottelat M, Bogutskaya N, Coad B, Mandrak N, Balderas SC, Bussing W, Stiassny ML, Skelton P, Allen GR, Unmack P, Naseka A, Ng R, Sindorf N, Robertson J, Armijo E, Higgins JV, Heibel TJ, Wikramanayake E, Olson D, López HL, Reis RE, Lundberg JG, Pérez MHS, Petry P. Freshwater ecoregions of the world: a new map of biogeographic units for freshwater biodiversity conservation. BioScience [serial on the Internet]. 2008; 58(5):403-14. Available from: https://doi.org/10.1641/B580507

Abràmoff $\mathrm{MD}$, Magalhães $\mathrm{PJ}$, Ram SJ. Image processing with ImageJ. Biophotonics Intern. 2004; 11(7):36-42.

Aguilera O, Lundberg J, Birindelli J, Pérez MHS, Jaramillo C, Sánchez-Villagra MR. Palaeontological evidence for the last temporal occurrence of the ancient western Amazonian River outflow into the Caribbean. PLoS One [serial on the Internet]. 2013; 8(9):e76202. Available from: https://doi.org/10.1371/ journal.pone.0076202

Albert JS, Antonelli A. Society for the Study of Systematic Biology symposium: Frontiers in Parametric Biogeography. Syst Biol [serial on the Internet]. 2017; 66(2):125-27. Available from: https://doi.org/10.1093/sysbio/syx036

Albert JS, Carvalho TP. Neogene assembly of modern faunas. In: Albert JS, Reis RE, editors. Historical Biogeography of Neotropical Freshwater Fishes. Berkeley: University of California Press; 2011. p.119-136.

Albert JS, Crampton WGR, The geography and ecology of diversification in Neotropical freshwaters. Nature Knowledge. 2010; 1:13-19.

Albert JS, Carvalho TP, Petry P, Holder MA, Maxime EL, Espino J, Corahua I, Quispe R, Rengifo B, Ortega H, Reis RE. Aquatic biodiversity in the Amazon: habitat specialization and 
geographic isolation promote species richness. Animals [serial on the Internet]. 2011b; 1(2):205-41. Available from: https:// doi.org/10.3390/ani1020205

Albert JS, Craig JM, Tagliacollo VA, Petry P. Upland and lowland fishes: A test of the River Capture Hypothesis. In: Hoorn CM, Perrigo A, Antonelli A, editors. Mountains, Climate and Biodiversity. Cambridge: Wiley Press; 2018. p.273-294.

Albert JS, Lovejoy NR, Crampton WGR. Miocene tectonism and the separation of cis-and trans-Andean river basins: evidence from Neotropical fishes. J South Am Earth Sci [serial on the Internet]. 2006; 21(1-2):14-27. Available from: https://doi. org/10.1016/j.jsames.2005.07.010

Albert JS, Petry P, Reis RE. Major biogeographic and phylogenetic patterns. In: Albert JS, Reis RE, editors. Historical Biogeography of Neotropical Freshwater Fishes. Berkeley: University of California Press; 2011a. p.21-59.

Albert JS, Schoolmaster DR, Jr., Tagliacollo VA, Duke-Sylvester SM. Barrier displacement on a neutral landscape: Towards a theory of continental biogeography. Syst Biol [serial on the Internet]. 2017; 66(2):167-82. Available from: https://doi. org/10.1093/sysbio/syw080

Aleixo A. Historical diversification of a terra-firme forest bird superspecies: a phylogeographic perspective on the role of different hypotheses of Amazonian diversification. Evolution [serial on the Internet]. 2004; 58(6):1303-17. Available from: https://doi.org/10.1111/j.0014-3820.2004.tb01709.x

Alfaro JWL, Boubli JP, Paim FP, Ribas CC, da Silva MNF, Messias MR, Röhe F, Mercês MP, Silva Júnior JS, Silva CR, Pinho GM, Koshkarian G, Nguyen MTT, Harada ML, Rabelo RM, Queiroz HL, Alfaro ME, Farias IP. Biogeography of squirrel monkeys (genus Saimiri): South-central Amazon origin and rapid pan-Amazonian diversification of a lowland primate. Mol Phylogenet Evol [serial on the Internet]. 2015; 82(Part B):436-54. Available from: https://doi.org/10.1016/j. ympev.2014.09.004

Allard T, Gautheron C, Bressan-Riffel S, Balan E, Soares BF, PinnaJamme R, Derycke A, Morin G, Buenoe GT, do Nascimento N. Combined dating of goethites and kaolinites from ferruginous duricrusts. Deciphering the Late Neogene erosion history of Central Amazonia. Chem Geol [serial on the Internet]. 2018; 479:136-50. Available from: https://doi.org/10.1016/j. chemgeo.2018.01.004

Anderson VJ, Horton BK, Saylor JE, Mora A, Tesón E, Breecker DO, Ketcham RA. Andean topographic growth and basement uplift in southern Colombia: Implications for the evolution of the Magdalena, Orinoco, and Amazon river systems. Geosphere [serial on the Internet]. 2016; 12(4):1235-56. Available from: https://doi.org/10.1130/GES01294.1

Antoine P-O, Salas-Gismondi R, Pujos F, Ganerød M, Marivaux L. Western Amazonia as a hotspot of mammalian biodiversity throughout the Cenozoic. J Mamm Evol [serial on the Internet]. 2017; 24(1):5-17. Available from: https://doi.org/10.1007/ s10914-016-9333-1

Antonelli A, Sanmartín I. Why are there so many plant species in the Neotropics? Taxon. 2011; 60(2):403-14.

Antonelli A, Nylander JAA, Persson C, Sanmartín I. Tracing the impact of the Andean uplift on Neotropical plant evolution. Proc Natl Acad Sci U S A [serial on the Internet]. 2009; 106(24):9749-54. Available from: https://doi.org/10.1073/ pnas.0811421106

Antonelli A, Quijada-Mascareñas A, Crawford AJ, Bates JM, Velazco PM, Wüster W. Molecular studies and phylogeography of Amazonian tetrapods and their relation to geological and climatic models. In: Hoorn CM, Wesselingh F, editors. Amazonia: landscape and species evolution: a look into the past. New York: John Wiley \& Sons; 2010. p.386-404.

Ashworth PJ, Lewin J. How do big rivers come to be different? Earth Sci Rev [serial on the Internet]. 2012; 114(1-2):84-107. Available from: https://doi.org/10.1016/j.earscirev.2012.05.003

Assine ML, Merino ER, Pupim FN, Warren LV, Guerreiro RL, McGlue MM. Geology and geomorphology of the Pantanal basin. In: Bergier I, Assine ML, editors. Dynamics of the Pantanal Wetland in South America. Swizerland: Springer Cham; 2015. p.23-50.

Bahlburg H, Vervoort JD, Du Frane SA, Bock B, Augustsson C, Reimann C. Timing of crust formation and recycling in accretionary orogens: Insights learned from the western margin of South America. Earth Sci Rev [serial on the Internet]. 2009; 97(1-4):215-41. Available from: https://doi.org/10.1016/j. earscirev.2009.10.006

Barckhausen U, Ranero CR, Cande SC, Engels M, Weinrebe W. Birth of an intraoceanic spreading center. Geology [serial on the Internet]. 2008; 36(10):767-70. Available from: https://doi. org/10.1130/G25056A.1

Beard JS. Paleodrainage and the geomorphic evolution of passive margins in southwestern Australia. Z Geomorphol. 2003; 47:273-88.

Bermúdez MA, Hoorn C, Bernet M, Carrillo E, van der Beek PA, Garver JI, Mora JL, Mehrkian K. The detrital record of late-Miocene to Pliocene surface uplift and exhumation of the Venezuelan Andes in the Maracaibo and Barinas foreland basins. Basin Res [serial on the Internet]. 2015; 29(S1):370-95. Available from: https://doi.org/10.1111/bre.12154

Bishop P. Drainage rearrangement by river capture, beheading and diversion. Prog Phys Geogr. 1995; 19(4):449-73.

Bishop P. Long-term landscape evolution: linking tectonics and surface processes. Earth Surf Process Landf [serial on the Internet]. 2007; 32(3):329-65. Available from: https://doi. org/10.1002/esp.1493

Black BA, Perron JT, Hemingway D, Bailey E, Nimmo F, Zebker H. Global drainage patterns and the origins of topographic relief on Earth Mars and Titan. Science [serial on the Internet]. 2017; 356(6339):727-31. Available from: https://doi.org/10.1126/ science.aag0171

Branner JC. Outlines of the geology of Brazil to accompany the geologic map of Brazil. Geol Soc Am Bull.1919; 30(2):189338.

Brookfield ME. The evolution of the great river systems of southern Asia during the Cenozoic India-Asia collision: rivers draining southwards. Geomorphology. 1998; 22(3-4):285-312.

Burridge CP, Craw D, Waters JM. River capture, range expansion, and cladogenesis: the genetic signature of freshwater vicariance. Evolution [serial on the Internet]. 2006; 60(5):103849. Available from: https://doi.org/10.1111/j.0014-3820.2006. tb01181.x

Campbell KE, Jr., Heizler M, Frailey CD, Romero-Pittman L, Prothero DR. Upper Cenozoic chronostratigraphy of the southwestern Amazon Basin. Geology [serial on the Internet]. 2001; 29(7):595-98. Available from: https://doi. org/10.1130/0091-7613(2001)029<0595:UCCOTS $>2.0 . C O ; 2$

Caputo MV, Soares EAA. Eustatic and tectonic change effects in the reversion of the transcontinental Amazon River drainage system. Braz J Geol [serial on the Internet]. 2016; 46(2):301-28. Available from: https://doi.org/10.1590/2317-4889201620160066 
Caputo MV, Soares EAA. Eustatic and tectonic change effects in the reversion of the transcontinental Amazon River drainage system. Braz J Geol. 2016; 46(2):301-28.

Carneiro L, Bravo GA, Aristizábal N, Cuervo AM, Aleixo A. Molecular systematics and biogeography of lowland antpittas (Aves Grallariidae): The role of vicariance and dispersal in the diversification of a widespread Neotropical lineage. Mol Phylogenet Evol [serial on the Internet]. 2018; 120:375-89. Available from: https://doi.org/10.1016/j.ympev.2017.11.019

Carrea C, Anderson LV, Craw D, Waters JM, Burridge CP. The significance of past interdrainage connectivity for studies of diversity distribution and movement of freshwater-limited taxa within a catchment. J Biogeogr [serial on the Internet]. 2014; 41(3):536-47. Available from: https://doi.org/10.1111/jbi.12207

Carvalho TP, Albert JS. The Amazon-Paraguay divide. In: Albert JS, Reis RE (Eds.). Historical biogeography of Neotropical freshwater fishes. University of California Press, Berkeley. 2011. p.93-202.

Chiarabba C, De Gori P, Faccenna C, Speranza F, Seccia D, Dionicio V, Prieto GA. Subduction system and flat slab beneath the Eastern Cordillera of Colombia. Geochem Geophys Geosyst [serial on the Internet]. 2016; 17(1):16-27. Available from: https://doi.org/10.1002/2015GC006048

Church M. Geomorphic thresholds in riverine landscapes. Freshw Biol [serial on the Internet]. 2002; 47(4):541-57. Available from: https://doi.org/10.1046/j.1365-2427.2002.00919.x

Conti LA. Paleodrainage Systems. In: Javaid MS, editor. Drainage Systems. Rijeka: InTech; 2012. p.4-20.

Cordani UG, Sato K. Crustal evolution of the South American Platform based on $\mathrm{Nd}$ isotopic systematics on granitoid rocks. Episodes. 1999; 22(3):167-73.

Costa JBS, Bemerguy RL, Hasui Y, Borges MS. Tectonics and paleogeography along the Amazon River. J South Am Earth Sci [serial on the Internet]. 2001; 14(4):335-47. Available from: https://doi.org/10.1016/S0895-9811(01)00025-6

Courtillot V, Davaille A, Besse J, Stock J. Three distinct types of hotspots in the Earth's mantle. Earth Planet Sci Lett [serial on the Internet]. 2003; 205(3-4):295-308. Available from: https:// doi.org/10.1016/S0012-821X(02)01048-8

Cowman PF, Bellwood DR. Coral reefs as drivers of cladogenesis: expanding coral reefs cryptic extinction events and the development of biodiversity hotspots. J Evol Biol [serial on the Internet]. 2011; 24(12):2543-62. Available from: https://doi. org/10.1111/j.1420-9101.2011.02391.x

Cracraft J. Continental drift, palaeoclimatology, and the evolution and biogeography of birds. J Zool [serial on the Internet]. 1973; 169:455-545. Available from: https://doi. org/10.1111/j.1469-7998.1973.tb03122.x

Cracraft J. Historical biogeography and patterns of differentiation within the South American avifauna: areas of endemism. Ornithol Monogr [serial on the Internet]. 1985; 36:49-84. Available from: https://www.jstor.org/stable/40168278

Crampton WGR. An ecological perspective on diversity and distributions. In: Albert JS, Reis RE, editors. Historical biogeography of neotropical freshwater fishes. Berkeley: University of California Press; 2011. p.165-189.

Craw D, Upton P, Burridge CP, Wallis GP, Waters JM. Rapid biological speciation driven by tectonic evolution in New Zealand. Nat Geosci [serial on the Internet]. 2016; 9:140-44. Available from: https://doi.org/10.1038/ngeo2618

Cremon ÉH, Rossetti DF, Sawakuchi AO, Cohen MCL. The role of tectonics and climate in the late Quaternary evolution of a northern Amazonian River. Geomorphology [serial on the Internet]. 2016; 271:22-39. Available from: https://doi. org/10.1016/j.geomorph.2016.07.030

Dagosta FC, de Pinna MD. Biogeography of Amazonian fishes: deconstructing river basins as biogeographic units. Neotrop Ichthyol [serial on the Internet]. 2017; 15(3):e170034. Available from: https://doi.org/10.1590/1982-0224-20170034

Davis WM. The Rivers and Valleys of Pennsylvania. Natl Geogr Mag. 1889; 1:269-304.

de Almeida FFM, de Brito Neves BB, Carneiro CDR. The origin and evolution of the South American Platform. Earth Sci Rev [serial on the Internet]. 2000; 50(1-2):77-111. Available from: https://doi.org/10.1016/S0012-8252(99)00072-0

de Alvarenga CJ, Boggiani PC, Babinski M, Dardenne, MA, Figueiredo M, Santos RV, Dantas EL. The Amazonian palaeocontinent. Dev Precamb Geol. 2009; 16:15-28.

De Assis RL, Wittmann F. Forest structure and tree species composition of the understory of two central Amazonian várzea forests of contrasting flood heights. Flora [serial on the Internet]. 2011; 206(3):251-60. Available from: https://doi. org/10.1016/j.flora.2010.11.002

Dias MS, Oberdorff T, Hugueny B, Leprieur F, Jézéquel C, Cornu J-F, Brosse S, Grenouillet G, Tedesco PA. Global imprint of historical connectivity on freshwater fish biodiversity Ecol Lett [serial on the Internet]. 2014; 17(9):1130-40. Available from: https://doi.org/10.1111/ele.12319

Díaz de Gamero MLD. The changing course of the Orinoco River during the Neogene: a review. Palaeogeogr Palaeoclimatol Palaeoecol [serial on the Internet]. 1996; 123(1-4):385-402. Available from: https://doi.org/10.1016/0031-0182(96)00115-0

Dobson DM, Dickens GR, Rea DK. Terrigenous sediment at Ceará Rise In: Shackleton NJ, Curry WB, Richter C, Bralower TJ, editors. Proceeding of the Ocean Drilling Program, Scientific Results. Texas: Ocean Drilling Program, College Station; 1997. p.465-473.

Dobson DM, Dickens GR, Rea DK. Terrigenous sediment on Ceará Rise: a Cenozoic record of South American orogeny and erosion. Palaeogeogr Palaeoclimatol Palaeoecol [serial on the Internet]. 2001; 165(3-4):215-29. Available from: https://doi. org/10.1016/S0031-0182(00)00161-9

Dumont JF. Neotectonics of the subandes-Brazilian craton boundary using geomorphological data: the Maranon and Beni basins. Tectonophysics [serial on the Internet]. 1996; 259(1-3):137-51. Available from: https://doi.org/10.1016/0040-1951(95)00200-6

Eakin CM, Lithgow-Bertelloni C, Dávila FM. Influence of Peruvian flat-subduction dynamics on the evolution of western Amazonia. Earth Planet Sci Lett [serial on the Internet]. 2014; 404:250-60. Available from: https://doi.org/10.1016/j. eps1.2014.07.027

Eigenmann CH, Allen WR. Fishes of Western South America, I: The intercordilleran and Amazonian Lowlands of Peru; II: The High Pampas, Bolivia, and Northern of Chile, with a revision of the Peruvian Gymnotidae and of the genus Orestias. Lexington: University of Kentucky; 1942.

Einsele G. Sedimentary basins: evolution, facies, and sediment budget. Heidelberg; Springer Verlag; 1992.

Evans KM, Crampton WGR, Albert JS. Taxonomic revision of the deep channel electric fish genus Sternarchella (Teleostei: Gymnotiformes: Apteronotidae) with descriptions of two new species. Neotrop Ichthyol [serial on the Internet]. 2017a; 15(2):e160168. Available from: https://doi.org/10.1590/19820224-20160168 
Evans KM, Waltz B, Tagliacollo V, Chakrabarty P, Albert JS. Why the short face? Developmental disintegration of the neurocranium drives convergent evolution in neotropical electric fishes. Ecol Evol [serial on the Internet]. 2017b; 7(6):1783-801. Available from: https://doi.org/10.1002/ece3.2704

Fagan WF. Connectivity fragmentation and extinction risk in dendritic metapopulations. Ecology [serial on the Internet]. 2002; 83(12):3243-49. Available from: https://doi. org/10.1890/0012-9658(2002)083[3243:CFAERI]2.0.CO;2

Fernandes AM, Wink M, Sardelli CH, Aleixo A. Multiple speciation across the Andes and throughout Amazonia: the case of the spot-backed antbird species complex (Hylophylax naevius/ Hylophylax naevioides). J Biogeogr [serial on the Internet]. 2014; 41(6):1094-104. Available from: https://doi.org/10.1111/ jbi. 12277

Figueiredo J, Hoorn C, Van der Ven P, Soares E. Late Miocene onset of the Amazon River and the Amazon deep-sea fan: Evidence from the Foz do Amazonas Basin. Geology [serial on the Internet]. 2009; 37(7):619-22. Available from: https://doi. org/10.1130/G25567A.1

Figueiredo J, Hoorn C, Van der Ven P, Soares E. Late Miocene onset of the Amazon River and the Amazon deep-sea fan: Evidence from the Foz do Amazonas Basin: Reply. Geology [serial on the Internet]. 2010; 38(7):e213. Available from: https://doi.org/10.1130/G31057Y.1

Fine PVA, Ree RH. Evidence for a time-integrated species-area effect on the latitudinal gradient in tree diversity. Am Nat [serial on the Internet]. 2006; 168:796-804. Available from: https://doi.org/10.1086/508635

Forte AM, Peltier WR, Dziewonski AM, Woodward RL. Dynamic surface topography: A new interpretation based upon mantle flow models derived from seismic tomography. Geophys Res Lett [serial on the Internet]. 1993; 20(3):225-28. Available from: https://doi.org/10.1029/93GL00249

Frailey CD, Lavina EL, Rancy A, Souza Filho JP. A proposed Pleistocene/Holocene lake in the Amazon Basin and its significance to Amazonian geology and biogeography. Acta Amazon [serial on the Internet]. 1988; 18(3-4):119-43. Available from: https://doi.org/10.1590/1809-43921988183143

Galloway WE, Whiteaker TL, Ganey-Curry P. History of Cenozoic North American drainage basin evolution, sediment yield, and accumulation in the Gulf of Mexico basin. Geosphere [serial on the Internet]. 2011; 7(4):938-73. Available from: https://doi. org/10.1130/GES00647.1

Garzione CN, McQuarrie N, Perez ND, Ehlers TA, Beck SL, Kar $\mathrm{N}$, Eichelberger N, Chapman AD, Ward KM, Ducea MN, Lease RO, Poulsen CJ, Wagner LS, Saylor JE, Zandt G, Horton BK. Tectonic evolution of the Central Andean plateau and implications for the growth of plateaus. Annu Rev EarthPlanet Sci [serial on the Internet]. 2017; 45:529-59. Available from: https://doi.org/10.1146/annurev-earth-063016-020612

Gasparini NM, Whipple KX, Bras RL. Predictions of steady state and transient landscape morphology using sediment-fluxdependent river incision models. J Geophys Res Earth Surf [serial on the Internet]. 2007; 112(F3):F03S09. Available from: https://doi.org/10.1029/2006JF000567

Gilchrist AR, Summerfield MA. Denudation, isostasy and landscape evolution. Earth Surf Process Landf [serial on the Internet]. 1991; 16:555-62. Available from: https://doi. org/10.1002/esp.3290160607

Godoy JR, Petts G, Salo J. Riparian flooded forests of the Orinoco and Amazon basins: a comparative review. Biodivers Conserv [serial on the Internet]. 1999; 8(4):551-86. Available from: https://doi.org/10.1023/A:1008846531941

Goldberg SL, Stokes M, Perron JT. Ongoing River Capture in the Amazon via Secondary Channel Flow. Cambridge: AGU Fall Meeting Abstracts; 2017.

Gorini C, Haq BU, dos Reis AT, Silva CG, Cruz A, Soares E, Grangeon D. Late Neogene sequence stratigraphic evolution of the Foz do Amazonas Basin Brazil. Terra Nova [serial on the Internet]. 2014; 26(3):179-85. Available from: https://doi. org/10.1111/ter. 12083

Goudie AS. The drainage of Africa since the Cretaceous. Geomorphology [serial on the Internet]. 2005; 67(34):437-56. Available from: https://doi.org/10.1016/j. geomorph.2004.11.008

Goulding M, Barthem R, Ferreira EJG, Duenas R. The Smithsonian atlas of the Amazon. 2003; Washington: Smithsonian Books.

Graham A. The age and diversification of terrestrial New World ecosystems through Cretaceous and Cenozoic time. Am J Bot [serial on the Internet]. 2011; 98(3):336-51. Available from: https://doi.org/10.3732/ajb.1000353

Gregory-Wodzicki KM. Uplift history of the Central and Northern Andes: A review. GSA Bull [serial on the Internet]. 2000; 112(7):1091-105. Available from: https://doi. org/10.1130/0016-7606(2000)112<1091:UHOTCA >2.0.CO;2

Gross M, Piller WE, Ramos MI, da Silva Paz JD. Late Miocene sedimentary environments in south-western Amazonia (Solimões formation; Brazil). J S Am Earth Sci. 2011; 32(2):169-81.

Gupta A. Large Rivers: Geomorphology and Management. Chichester: John Wiley \& Sons; 2007.

Harel M-A, Mudd SM, Attal M. Global analysis of the stream power law parameters based on worldwide 10Be denudation rates. Geomorphology [serial on the Internet]. 2016; 268:184-96. Available from: https://doi.org/10.1016/j. geomorph.2016.05.035

Hartmann LA. The Mesoproterozoic supercontinent Atlantica in the Brazilian shield-review of geological and $\mathrm{U}-\mathrm{Pb}$ zircon and $\mathrm{Sm}-\mathrm{Nd}$ isotopic evidence. Gondwana Res [serial on the Internet]. 2002; 5(1):157-63. Available from: https://doi. org/10.1016/S1342-937X(05)70899-6

Hawkesworth C, Cawood P, Dhuime B. Continental growth and the crustal record. Tectonophysics [serial on the Internet]. 2013; 609:651-60. Available from: https://doi.org/10.1016/j. tecto.2013.08.013

Heinrich S, Zonneveld KAF. Influence of the Amazon River development and constriction of the Central American Seaway on Middle/late Miocene oceanic conditions at the Ceará Rise. Palaeogeogr Palaeoclimatol Palaeoecol [serial on the Internet]. 2013; 386:599-606. Available from: https://doi.org/10.1016/j. palaeo.2013.06.026

Hoorn CM. Marine incursions and the influence of Andean tectonics on the Miocene depositional history of northwestern Amazonia: results of a palynostratigraphic study. Palaeogeogr Palaeoclimatol Palaeoecol [serial on the Internet]. 1993; 105(34):267-309. Available from: https://doi.org/10.1016/00310182(93)90087-Y

Hoorn CM, Bogotá-A GR, Romero-Baez M, Lammertsma EI, Flantua SGA, Dantas EL, Dino R, do Carmo DA, Chemale F, Jr. The Amazon at sea: Onset and stages of the Amazon River from a marine record, with special reference to Neogene plant turnover in the drainage basin. Glob Planet Change [serial on the Internet]. 2017; 153:51-65. Available from: https://doi. org/10.1016/j.gloplacha.2017.02.005 
Hoorn CM, Guerrero J, Sarmiento GA, Lorente MA. Andean tectonics as a cause for changing drainage patterns in Miocene northern South America. Geology [serial on the Internet]. 1995; 23(3):237-40. Available from: https://doi.org/10.1130/00917613(1995)023\%3C0237:ATAACF\%3E2.3.CO;2

Hoorn, Wesselingh, 2010

Hoorn CM, Wesselingh FP, Ter Steege H, Bermudez MA, Mora A, Sevink J, Sanmartín I, Sanchez-Meseguer A, Anderson CL, Figueiredo JP, Jaramillo C, Riff D, Negri FR, Hooghiemstra H, Lundberg J, Stadler T, Särkinen T, Antonelli A. Amazonia through time: Andean uplift climate change, landscape evolution and biodiversity. Science [serial on the Internet]. 2010b; 330(6006):927-31. Available from: https://doi. org/10.1126/science. 1194585

Hoorn C, Wesselingh FP, Hovikoski J, Guerrero J. The development of the Amazonian mega-wetland (Miocene; Brazil Colombia Peru Bolivia). In: Hoorn C, Wesselingh FP, editors. Amazonia, landscape and species evolution: A look into the past. New York: John Wiley \& Sons; 2010a. p.123-142.

Horbe AMC, Motta MB, de Almeida CM, Dantas EL, Vieira LC. Provenance of Pliocene and recent sedimentary deposits in western Amazônia Brazil: Consequences for the paleodrainage of the Solimões-Amazonas River. Sedimentary Geology [serial on the Internet]. 2013; 296:9-20. Available from: https://doi. org/10.1016/j.sedgeo.2013.07.007

Horton BK. Sedimentary record of Andean mountain building. Earth Sci Rev [serial on the Internet]. 2017;178:279-309. Available from: https://doi.org/10.1016/j.earscirev.2017.11.025

Horton BK, Perez ND, Fitch JD, Saylor JE. Punctuated shortening and subsidence in the Altiplano Plateau of southern Peru: Implications for early Andean mountain building. Lithosphere, 2015a; 7(2):117-37.

Horton BK, Anderson VJ, Caballero V, Saylor JE, Nie J, Parra M, Mora A. Application of detrital zircon U-Pb geochronology to surface and subsurface correlations of provenance, paleodrainage, and tectonics of the Middle Magdalena Valley Basin of Colombia. Geosphere. 2015b; 11(6):1790-811.

Hovikoski J, Wesselingh FP, Räsänen M, Gingras M, Vonhof HB. Marine influence in Amazonia: Evidence from the geological record. In: Hoorn C, Wesselingh FP, editors. Amazonia, Landscape and Species Evolution. New York: John Wiley \& Sons; 2010. p.143-161.

Hughes CE, Pennington RT, Antonelli A. Neotropical plant evolution: assembling the big picture. Bot J Linn Soc [serial on the Internet]. 2013; 171(1):1-18. Available from: https://doi. org/10.1111/boj.12006

Hurtado C, Roddaz M, Santos RV, Baby P, Antoine P-O, Dantas EL. Late Cretaceous-early Paleocene drainage shift of Amazonian rivers driven by Equatorial Atlantic Ocean opening and Andean uplift as deduced from the provenance of northern Peruvian sedimentary rocks (Huallaga basin). Gondwana Res [serial on the Internet]. 2018; 63:152-68. Available from: https://doi. org/10.1016/jgr201805012.

Irion G, Kalliola R. Long-term landscape development processes in Amazonia. In: Hoorn CM, Wesselingh FP, editors. Amazonia, Landscape and Species Evolution: A look into the past. New York: John Wiley \& Sons; 2010. p.185-197.

Iturralde-Vinent M, MacPhee RDE. Paleogeography of the Caribbean region: implications for Cenozoic biogeography. Bull Am Mus Nat Hist. 1999; 238:1-95.

Jaramillo C, Hoorn C, Silva SA, Leite F, Herrera F, Quiroz L, Dino $\mathrm{R}$, Antonioli L. The origin of the modern Amazon rainforest: implications of the palynological and palaeobotanical record. In: Hoorn CM, Wesselingh FP, editors. Amazonia, Landscape and Species Evolution: A look into the past. New York: John Wiley \& Sons; 2010 p.317-334.

Jaramillo C, Romero I, D'Apolito C, Bayona G, Duarte E, Louwye S, Escobar J, Luque J, Carrillo-Briceño JD, Zapata V, Mora A, Schouten S, Zavada M, Harrington G, Ortiz J, Wesselingh FP. Miocene flooding events of western Amazonia. Sci Adv [serial on the Internet]. 2017; 3(5):e16016932017. Available from: https://doi.org/10.1126/sciadv.1601693

Johansson A. Baltica Amazonia and the SAMBA connection 1000 million years of neighbourhood during the Proterozoic? Precambrian Res [serial on the Internet]. 2009; 175(14):221-34. Available from: https://doi.org/10.1016/j. precamres.2009.09.011

Jongman RHG, Smith JK, Moreno EC, Loedeman JH. Assessing flooding patterns in Llanos of the Apure Region (Venezuela) using radar images. Ecotrópicos. 2008; 21(1):34-45.

Jordan TE. Thrust loads and foreland basin evolution Cretaceous western United States. Am Assoc Pet Geol Bull. 1981; 65(12):2506-20.

Junk WJ. Wetlands of tropical south America. In: Whigham DF, Dykyowá D, Hejný S, editors. Wetlands of the world: Inventory, ecology and management. Volume I. Dordrecht: Springer; 1993. p.679-739.

Kissling WD, Eiserhardt WL, Baker WJ, Borchsenius F, Couvreur TLP, Balslev H, Svenning J-C. Cenozoic imprints on the phylogenetic structure of palm species assemblages worldwide. Proc Natl Acad Sci U S A [serial on the Internet]. 2012; 109:7379-84. Available from: https://doi.org/10.1073/ pnas. 1120467109

Knorr G, Lohmann G. Southern Ocean origin for the resumption of Atlantic thermohaline circulation during deglaciation. Nature [serial on the Internet]. 2003; 424(6948):532-36. Available from: https://doi.org/10.1038/nature01855

Knouft JH, Page LM. The evolution of body size in extant groups of North American freshwater fishes: speciation size distributions and Cope's rule. Am Nat [serial on the Internet]. 2003; 161(3):413-21. Available from: https://doi.org/10.1086/346133

Kooi H, Beaumont C. Large-scale geomorphology: Classical concepts reconciled and integrated with contemporary ideas via a surface processes model. J Geophys Res Solid Earth [serial on the Internet]. 1996; 101(B2):3361-86. Available from: https://doi.org/10.1029/95JB01861

Lague D, Hovius N, Davy P. Discharge variability and the bedrock channel profile. J Geophys Res Earth Surf [serial on the Internet]. 2005; 110(F4):F04006. Available from: https://doi. org/10.1029/2004JF000259

Lambert D. The Field Guide to Geology. New York: Facts on Files; 1998.

Lammertsma EI, Troelstra SR, Flores J-A, Sangiorgi F, Chemale F, Jr., do Carmo DA, Hoorn C. Primary productivity in the western tropical Atlantic follows Neogene Amazon River evolution. Palaeogeogr Palaeoclimatol Palaeoecol [serial on the Internet]. 2018; 506:12-21. Available from: https://doi. org/10.1016/j.palaeo.2018.05.048

Latrubesse EM, Cozzuol M, da Silva-Caminha SAF, Rigsby CA, Absy ML, Jaramillo C. The late Miocene paleogeography of the Amazon Basin and the evolution of the Amazon River system. Earth Sci Rev [serial on the Internet]. 2010; 99(3-4):99-124. Available from: https://doi.org/10.1016/j. earscirev.2010.02.005 
Lehner B, Verdin K, Jarvis A. New global hydrography derived from spaceborne elevation data. Eos [serial on the Internet]. 2008; 89(10):93-94. Available from: https://doi. org/10.1029/2008EO100001

Linder HP, Crisp MD. Nothofagus and Pacific biogeography. Cladistics [serial on the Internet]. 1995; 11(1):5-32. Available from: https://doi.org/10.1111/j.1096-0031.1995.tb00002.x

López-Fernández H, Albert JS. Paleogene radiations. In: Albert JS, Reis RE, editors. Historical biogeography of Neotropical freshwater fishes. Berkeley: University of California Press; 2011. p.105-117.

Louterbach M, Roddaz M, Antoine P-O, Marivaux L, Adnet S, Bailleul J, Dantas E, Santos RV, Chemale F, Jr., Baby P, Sanchez C, Calderon Y. Provenance record of late Maastrichtian, late Paleocene Andean Mountain building in the Amazonian retroarc foreland basin (Madre de Dios basin Peru). Terra Nova [serial on the Internet]. 2017; 30(1):17-23. Available from: https://doi.org/10.1111/ter.12303

Lovejoy NR, Willis SC, Albert JS. Molecular signatures of Neogene biogeographical events in the Amazon fish fauna. In: Hoorn CM, Wesselingh FP, editors. Amazonia, landscape and species evolution: A look into the past. New York: John Wiley \& Sons; 2010. p.405-417.

Lundberg JG. The temporal context for the diversification of Neotropical fishes. In: Malabarba LR, Reis RE, Vari RP, Lucena ZMS, Lucena CAS, editors. Phylogeny and classification of Neotropical fishes. Porto Alegre: Edipucrs; 1998. p.49-68.

Lundberg JG, Marshall LG, Guerrero J, Horton B, Malabarba MCSL, Wesselingh FP. The stage for Neotropical fish diversification: a history of tropical South American rivers. In: Malabarba LR, Reis RE, Vari RP, Lucena ZMS, Lucena CAS, editors. Phylogeny and classification of Neotropical fishes. Porto Alegre: Edipucrs; 1998. p.13-48.

Mapes RW. Past and present provenance of the Amazon River. [PhD Thesis]. Chapel Hill, NC: The University of North Carolina at Chapel Hill; 2009.

Martins AC, Bochorny T, Pérez-Escobar OA, Chomicki G, Monteiro SHN, Smidt E. From tree tops to the ground: reversals to terrestrial habit in Galeandra orchids (Epidendroideae: Catasetinae). Mol Phylogenet Evol [serial on the Internet]. 2017; 127:952-60. Available from: https://doi.org/10.1016/j.ympev.2018.06.041

Melack JM, Hess LL. Remote sensing of the distribution and extent of wetlands in the Amazon basin. In: Junk W, Piedade M, Wittmann F, Schöngart J. Amazonian floodplain forests, Netherlands: Springer; 2010. p.43-59.

Menegazzo MC, Catuneanu O, Chang HK. The South American retroarc foreland system: the development of the Bauru Basin in the back-bulge province. Mar Petrol Geol. 2016; 73:131-56.

Merdith AS, Collins AS, Williams SE, Pisarevsky S, Foden JD, Archibald DB, Blades ML, Alessio BL, Armistead S, Plavsa D, Clark C, Müller RD. A full-plate global reconstruction of the Neoproterozoic. Gondwana Res [serial on the Internet]. 2017; 50:84-134. Available from: https://doi.org/10.1016/j. gr.2017.04.001

Miguez-Macho G, Fan Y. The role of groundwater in the Amazon water cycle: 1. Influence on seasonal streamflow, flooding and wetlands. J Geophys Res Atmos [serial on the Internet]. 2012; 117(D15):1-30. Available from: https://doi. org/10.1029/2012JD017539

Milliman JD. River inputs. In: Steele JH, Turekian KK, Thorpe SA, editors. Encyclopedia of Ocean Sciences. London: Academic Press; 2001. p.2419-2427.
Monroe JS, Wicander R, editors. The Changing Earth: Exploring Geology and Evolution. 2nd ed. Belmont (CA): Wadsworth Publishing Company; 1997.

Mora A, Baby P, Roddaz M, Parra M, Brusset S, Hermoza W, Espurt N. Tectonic History of the Andes and Sub-Andean Zones: Implications for the Development of the Amazon Drainage Basin. In: Hoorn CM, Wesselingh FP, editors. Amazonia, Landscape, and Species Evolution: A look into the past. New York: John Wiley \& Sons; 2010. p.38-60.

Moreno-Bernal JW. Fossil crocodilians from the high Guajira Peninsula of Colombia and the history of Neogene crocodilian diversity in tropical South America. [PhD Thesis on the Internet]. Lincoln: University of Nebraska; 2014. [cited 15 Sept 2018].

Murray AS, Olley JM. Precision and accuracy in the optically stimulated luminescence dating of sedimentary quartz: a status review. Geochronometria. 2002; 21:1-16.

Nelson G, Rosen DE, editors. Vicariance biogeography. A critique. In: Symposium Systematics Discussion Group of America. New York: Columbia University Press; 1979.

Nittrouer CA, DeMaster DJ. Sedimentary processes on the Amazon continental shelf: past present and future research. Cont Shelf Res [serial on the Internet]. 1986; 6(1-2):5-30. Available from: https://doi.org/10.1016/0278-4343(86)90051-8

Nogueira ACR, Silveira R, Guimarães JTF. Neogene-Quaternary sedimentary and paleovegetation history of the eastern Solimões Basin, central Amazon region. J South Am Earth Sci [serial on the Internet]. 2013; 46:89-99. Available from: https:// doi.org/10.1016/j.jsames.2013.05.004

Payolla BL, Bettencourt JS, Kozuch M, Leite WB, Jr., Fetter AH, Van Schmus WR. Geological evolution of the basement rocks in the east-central part of the Rondonia Tin Province, SW Amazonian Craton, Brazil: U-Pb and $\mathrm{Sm}-\mathrm{Nd}$ isotopic constraints. Precambrian Res [serial on the Internet]. 2002; 119(1-4):141-69. Available from: https://doi.org/10.1016/ S0301-9268(02)00121-3

Pérez-Consuegra N, Parra M, Jaramillo C, Silvestro D, Echeverri S, Montes C, Jaramillo JM, Escobar J. Provenance analysis of the Pliocene Ware Formation in the Guajira Peninsula, northern Colombia: Paleodrainage implications. J South Am Earth Sci [serial on the Internet]. 2018; 81:66-77. Available from: https:// doi.org/10.1016/j.jsames.2017.11.002

Pérez-Escobar OA, Chomicki G, Condamine FL, de Vos JM, Martins AC, Smidt E,C, Klitgård B, Gerlach G, Heinrichs J. Multiple geographical origins of environmental sex determination enhanced the diversification of Darwin's Favourite Orchids. Sci Rep [serial on the Internet]. 2017; 7(1):128-78. Available from: https://doi.org/10.1038/s41598-017-12300-y

Pfiffner OA, Gonzalez L. Mesozoic-Cenozoic evolution of the western margin of South America: Case study of the Peruvian Andes. Geosciences [serial on the Internet]. 2013; 3(2):262-310. Available from: https://doi.org/10.3390/geosciences3020262

Pielou EC. After the Ice Age: The Return of Life to Glaciated North America. Chicago: University of Chicago Press; 2008.

Pimentel ET, Hamza VM. Indications of regional scale groundwater flows in the Amazon Basins: Inferences from results of geothermal studies. J South Am Earth Sci [serial on the Internet]. 2012; 37:214-27. Available from: https://doi. org/10.1016/j.jsames.2012.03.007

Pimm SL, Jenkins CN, Abell R, Brooks TM, Gittleman JL, Joppa LN, Raven PH, Roberts CM, Sexton JO. The biodiversity of species and their rates of extinction distribution and protection. 
Science [serial on the Internet]. 2014; 344(6187):1246752. Available from: https://doi.org/10.1126/science.1246752

Potter PE. Significance and origin of big rivers. J Geo [serial on the Internet]. 1978; 86(1):13-33. Available from: https://doi. org/10.1086/649653

Potter PE. The Mesozoic and Cenozoic paleodrainage of South America: a natural history. J South Am Earth Sci [serial on the Internet]. 1997; 10(5-6):331-44. Available from: https://doi. org/10.1016/S0895-9811(97)00031-X

Potter PE, Hamblin WK. Big rivers worldwide. Part 1. Origins. Vol. 48. Provo: Brigham Young University Geology Studies; 2006.

Potter PE, Szatmari P. Global Miocene tectonics and the modern world. Earth Sci Rev [serial on the Internet]. 2009; 96(4):279-95. Available from: https://doi.org/10.1016/j. earscirev.2009.07.003

Pupim FN, Bierman PR, Assine ML, Rood DH, Silva A, Merino ER. Erosion rates and landscape evolution of the lowlands of the Upper Paraguay River basin (Brazil) from cosmogenic 10Be. Geomorphology [serial on the Internet]. 2015; 234:151-60. Available from: https://doi.org/10.1016/j. geomorph.2015.01.016

Räsänen ME, Linna AM, Santos JCR, Negri FR. Late Miocene tidal deposits in the Amazonian foreland basin. Science [serial on the Internet]. 1995; 269(5222):386-90. Available from: https://doi.org/10.1126/science.269.5222.386

Rebata LA, Räsänen H, Gingras MK, Vieira V, Barberi M, Irion G. Sedimentology and ichnology of tide-influenced Late Miocene successions in western Amazonia: the gradational transition between the Pebas and Nauta formations. J S Am Earth Sci. 2006; 21(1):96-119.

Reis RE, Albert JS, Di Dario F, Mincarone MM, Petry P, Rocha LA. Fish biodiversity and conservation in South America. J Fish Biol [serial on the Internet]. 2016; 89(1):12-47. Available from: https://doi.org/10.1111/jfb.13016

Renwick WH. Equilibrium, disequilibrium, and nonequilibrium landforms in the landscape. Geomorphology [serial on the Internet]. 1992; 5(3-5):265-76. Available from: https://doi. org/10.1016/0169-555X(92)90008-C

Rhodes EJ. Optically stimulated luminescence dating of sediments over the past 200,000 years. Annu Rev Earth Planetary Sci [serial on the Internet]. 2011; 39:461-88. Available from: https://doi.org/10.1146/annurev-earth-040610-133425

Ribas CC, Aleixo A, Gubili C, d'Horta FM, Brumfield RT, Cracraft J. Biogeography and diversification of Rhegmatorhina (Aves: Thamnophilidae): Implications for the evolution of Amazonian landscapes during the Quaternary. J Biogeogr [serial on the Internet]. 2018; 45(4):917-28. Available from: https://doi. org/10.1111/jbi.13169

Ribas CC, Aleixo A, Nogueira ACR, Miyaki CY, Cracraft J. A palaeobiogeographic model for biotic diversification within Amazonia over the past three million years. Proc R Soc B [serial on the Internet]. 2012; 279(1729):681-89. Available from: https://doi.org/10.1098/rspb.2011.1120

Ribeiro AC. Tectonic history and the biogeography of the freshwater fishes from the coastal drainages of eastern Brazil: an example of faunal evolution associated with a divergent continental margin. Neotrop Ichthyol. 2006; 4(2):225-46.

Ritter DF, Kochel RC, Miller JR. Process Geomorphology. 3rd ed. New York: McGraw-Hill; 1995.

Roberts RG, Jacobs Z, Li B, Jankowski NR, Cunningham AC, Rosenfeld AB. Optical dating in archaeology: thirty years in retrospect and grand challenges for the future. J Archaeol Sci [serial on the Internet]. 2015; 56:41-60. Available from: https:// doi.org/10.1016/j.jas.2015.02.028

Robinson TM (Ed.). Heraclitus: Fragments. A Text and Translation with Commentary. Toronto: University of Toronto Press; 1987.

Robinson CT, Tockner K, Ward JV. The fauna of dynamic riverine landscapes. Freshw Biol. 2002; 47(4):661-77.

Roddaz M, Hermoza W, Mora A, Baby P, Parra M, Christophoul F, Brusset S, Espurt N. Cenozoic sedimentary evolution of the Amazonian foreland basin system. In: Hoorn CM, Wesselingh FP, editors. Amazonia, Landscape and Species Evolution: A look into the past. New York: John Wiley \& Sons; 2010. p.6188.

Rodríguez-Tribaldos V, White NJ, Roberts GG, Hoggard MJ. Spatial and temporal uplift history of South America from calibrated drainage analysis. Geochem Geophys Geosyst [serial on the Internet]. 2017; 18(6):2321-53. Available from: https://doi.org/10.1002/2017GC006909

Rossetti DF, Cohen MCL, Tatumi SH, Sawakuchi AO, Cremon ÉH, Mittani JCR, Bertani TC, Munita CJAS, Tudela DRG, Yee M, Moya G. Mid-Late Pleistocene OSL chronology in western Amazonia and implications for the transcontinental Amazon pathway. Sediment Geol [serial on the Internet]. 2015; 330:1-15. Available from: https://doi.org/10.1016/j. sedgeo.2015.10.001

Roxo FF, Albert JS, Silva GS, Zawadzki CH, Foresti F, Oliveira C. Molecular phylogeny and biogeographic history of the armored Neotropical catfish subfamilies Hypoptopomatinae, Neoplecostominae and Otothyrinae (Siluriformes: Loricariidae). PLoS One [serial on the Internet]. 2014; 9(8):e105564. Available from: https://doi.org/10.1371/journal. pone. 0105564

Sacek V. Drainage reversal of the Amazon River due to the coupling of surface and lithospheric processes. Earth Planet Sci Lett [serial on the Internet]. 2014; 401:301-12. Available from: https://doi.org/10.1016/j.eps1.2014.06.022

Santos JC, Coloma LA, Summers K, Caldwell JP, Ree R, Cannatella DC. Amazonian amphibian diversity is primarily derived from late Miocene Andean lineages. PLoS Biol [serial on the Internet]. 2009; 7(3):e1000056. Available from: https:// doi.org/10.1371/journal.pbio.1000056

Schaller MF, Fan Y. River basins as groundwater exporters and importers: Implications for water cycle and climate modeling. J Geophys Res Atmos [serial on the Internet]. 2009; 114(D4):D04103. Available from: https://doi. org/10.1029/2008JD010636

Schuchert C. Geology of the Lower Amazon region. J Geol. 1906; 14:722-46

Shea JH. Twelve fallacies of uniformitarianism. Geology [serial on the Internet]. 1982; 10(9):455-60. Available from: https:// doi.org/10.1130/0091-7613(1982)10\%3C455:TFOU\%3E2.0. $\mathrm{CO} ; 2$

Shephard GE, Müller RD, Liu L, Gurnis M. Miocene drainage reversal of the Amazon River driven by plate-mantle interaction. Nat Geosci [serial on the Internet]. 2010; 3(12):870-75. Available from: https://doi.org/10.1038/ngeo1017

Simpson GG. Historical science. In: Albritton CC, editor. The fabric of geology. Reading: Addison Wesley; 1963. p.24-48.

Sklar LS, Dietrich WE. A mechanistic model for river incision into bedrock by saltating bed load. Water Resour Res [serial on the Internet]. 2004; 40(6):W06301. Available from: https://doi. org/10.1029/2003WR002496 
Smith BT, McCormack JE, Cuervo AM, Hickerson MJ, Aleixo A, Cadena CD, Pérez-Emán J, Burney CW, Xie X, Harvey MG, Faircloth BC, Glenn TC, Derryberry EP, Prejean J, Fields S, Brumfield RT. The drivers of tropical speciation. Nature [serial on the Internet]. 2014; 515(7527):406-09. Available from: https://doi.org/10.1038/nature13687

Smith GR, Badgley C, Eiting TP, Larson PS. Species diversity gradients in relation to geological history in North American freshwater fishes. Evol Ecol Res. 2010; 12:693-726.

Sousa-Neves T, Aleixo A, Sequiera F. Cryptic patterns of diversification of a widespread Amazonian Woodcreeper species complex (Aves: Dendrocolaptidae) inferred from multilocus phylogenetic analysis: implications for historical biogeography and taxonomy. Mol Phylogenet Evol [serial on the Internet]. 2013; 68(3):410-24. Available from: https://doi. org/10.1016/j.ympev.2013.04.018

Sparks JS, Smith WL. Phylogeny and biogeography of the Malagasy and Australasian rainbowfishes (Teleostei: Melanotaenioidei): Gondwanan vicariance and evolution in freshwater. Mol Phylogenet Evol [serial on the Internet]. 2004; 33(3):719-34. Available from: https://doi.org/10.1016/j.ympev.2004.07.002

Stanford JA, Ward JV. An ecosystem perspective of alluvial rivers: connectivity and the hyporheic corridor. J N Am Benthol Soc. 1993; 48-60.

Stanley SM. Macroevolution, Pattern and Process. Baltimore: Johns Hopkins University Press; 1979.

Sternberg HOR. Vales tectônicos na planície Amazônica? Rev Bras Estat. 1950; 12(4):3-26.

Stokes MF, Goldberg SL, Perron JT. Ongoing river capture in the Amazon. Geophys Res Lett [serial on the Internet]. 2018; 45(11):5545-52. Available from: https://doi. org/10,1029/2018GL0781292018

Tagliacollo VA, Duke-Sylvester SM, Matamoros WA, Chakrabarty $\mathrm{P}$, Albert JS. Coordinated dispersal and pre-isthmian assembly of the Central American ichthyofaunas. Systematic Biology [serial on the Internet]. 2017; 66(2):183-96. Available from: https://oi.org/10.1093/sysbio/syv064

Tagliacollo VA, Roxo FF, Duke-Sylvester SM, Oliveira C, Albert JS. Biogeographical signature of river capture events in Amazonian lowlands. J Biogeogr [serial on the Internet]. 2015; 42(12):234962. Available from: https://doi.org/10.1111/jbi.12594

Tedesco PA, Oberdorff T, Lasso CA, Zapata M, Hugueny B. Evidence of history in explaining diversity patterns in tropical riverine fish. J Biogeogr [serial on the Internet]. 2005; 32(11):1899-907. Available from: https://doi.org/10.1111/ j.1365-2699.2005.01345.x

Tedesco PA, Beauchard O, Bigorne R, Blanchet S, Buisson L, Conti L, Cornu J-F, Dias MS, Grenouillet G, Hugueny B, Jézéquel C, Leprieur F, Brosse S, Oberdorff T. A global database on freshwater fish species occurrence in drainage basins. Sci Data [serial on the Internet]. 2017; 4:170141. Available from: https://doi.org/10.1038/sdata.2017.141

Tedesco P,A, Leprieur F, Hugueny B, Brosse S, Dürr HH, Beauchard O, Busson F, Oberdorff T. Patterns and processes of global riverine fish endemism. Glob Ecol Biogeogr [serial on the Internet]. 2012; 21(10):977-87. Available from: https://doi. org/10.1111/j.1466-8238.2011.00749.x

Thomaz AT, Malabarba LR, Knowles LL. Genomic signatures of paleodrainages in a freshwater fish along the southeastern coast of Brazil: Genetic structure reflects past riverine properties. Heredity [serial on the Internet]. 2017; 119(4):287-94. Available from: https://doi.org/10.1038/hdy.2017.46
Thorn CE, Welford MR. The equilibrium concept in geomorphology. Ann Assoc Am Geogr [serial on the Internet]. 1994; 84(4):66696. Available from: https://doi.org/10.1111/j.1467-8306.1994. tb01882.x

Toivonen T, Mäki S, Kalliola R. The riverscape of Western Amazonia-A quantitative approach to the fluvial biogeography of the region. J Biogeogr [serial on the Internet]. 2007; 34:1374-87. Available from: https://doi.org/10.1111/j.13652699.2007.01741.x

van der Sleen P, Albert JS, editors. Field Guide to the Fishes of the Amazon Orinoco and Guianas. Princeton: Princeton University Press; 2017.

van Soelen EE, Kim J-H, Santos RV, Dantas EL, de Almeida FV, Pires JP, Roddaz M, Damsté JSS. A 30 Ma history of the Amazon River inferred from terrigenous sediments and organic matter on the Ceará Rise. Earth Planet Sci Lett [serial on the Internet]. 2017; 474:40-48. Available from: https://doi. org/10.1016/j.eps1.2017.06.025

Wallace AR. A narrative of travels on the Amazon and Rio Negro with an account of the native tribes and observations on the climate, geology and natural history of the Amazon Valley. London: Ward, Lock \& company; 1889.

Wanderley-Filho JR. Evolução estrutural da Bacia do Amazonas e sua relação com o embasamento. [Master thesis]. Belém, PA: Universidade Federal do Pará; 1991.

Wanderley-Filho JR, Eiras JF, da Cruz Cunha PR, van der Ven PH. The Paleozoic Solimões and Amazonas basins and the Acre foreland basin of Brazil. In: Hoorn CM, Wesselingh FP, editors. Amazonia, Landscape and Species Evolution: A Look into the Past. New York: John Wiley \& Sons; 2010. p.29-37.

Ward JV, Tockner K, Arscott DB, Claret C. Riverine landscape diversity. Freshw Biol [serial on the Internet]. 2002; 47(4):517-39. Available from: https://doi.org/10.1046/j.13652427.2002.00893.x

Webb CO, Ackerly DD, McPeek MA, Donoghue MJ. Phylogenies and community ecology. Annu Rev Ecol Syst [serial on the Internet]. 2002; 33:475-505. Available from: https://doi. org/10.1146/annurev.ecolsys.33.010802.150448

Webb SD. A history of savanna vertebrates in the New World Part I: North America. Ann Rev Ecol Syst. 1977; 8(1):355-80.

Wesselingh FP, Hoorn C, Kroonenberg SB, Antonelli A, Lundberg JG, Vonhof HB, Hooghiemstra H. On the origin of Amazonian landscapes and biodiversity: A synthesis. In: Hoorn C, Wesselingh FP (Eds). Amazonia, landscape and species evolution: a look into the past; 2010. p.421-31. WileyBlackwell Publishing.

Wesselingh FP, Hoorn C. Geological development of Amazon and Orinoco basins. In: Albert JS, Reis RE (Eds.). Historical biogeography of Neotropical freshwater fishes. University of California Press, Berkeley. 2011. p.59-67.

Wesselingh FP, Salo JA. A Miocene perspective on the evolution of the Amazonian biota. Scr Geo. 2006; 133:439-58.

Wesselingh FP, Räsänen ME, Irion G, Vonhof HB, Kaandorp R, Renema W, Pittman LR, Gingras M. Lake Pebas: a palaeoecological reconstruction of a Miocene long-lived lake complex in western Amazonia. Cainozoic Res. 2001; 1(1/2):35-68.

Whipple KX, Tucker GE. Dynamics of the stream-power river incision model: Implications for height limits of mountain ranges landscape response timescales and research needs. J Geophys Res Solid Earth[serial on the Internet]. 1999; 104(B8):1766174. Available from: https://doi.org/10.1029/1999JB900120 
Whipple KX, DiBiase RA, Ouimet WB, Forte AM. Preservation or piracy: Diagnosing low-relief high-elevation surface formation mechanisms. Geology [serial on the Internet]. 2017; 45(1):9194. Available from: https://doi.org/10.1130/G38490.1

Wiens JA. Riverine landscapes: taking landscape ecology into the water. Freshw Biol [serial on the Internet]. 2002; 47(4):50115. Available from: https://doi.org/doi.org/10.1046/j.13652427.2002.00887.x

Wiens JJ, Donoghue MJ. Historical biogeography ecology and species richness. Trends Ecol Evol [serial on the Internet]. 2004; 19(12):639-44. Available from: https://doi.org/10.1016/j. tree.2004.09.011

Wiley EO. Vicariance biogeography. Ann Rev Ecol Syst. 1988; 19(1):513-42.

Wilkinson MJ, Marshall LG, Lundberg JG, Kreslavsky MH. Megafan environments in northern South America and their impact on Amazon Neogene aquatic ecosystems. In: Hoorn $\mathrm{CM}$, Wesselingh F editors. Amazonia, Landscape and species evolution: A look into the past. New York: John Wiley \& Sons. 2010. p.162-184.

Willenbring JK, Codilean AT, McElroy B. Earth is (mostly) flat: Apportionment of the flux of continental sediment over millennial time scales. Geology [serial on the Internet]. 2014; 41(3):343-46. Available from: https://doi.org/doi.org/10.1130/ G33918.1

Willett SD, McCoy SW, Perron JT, Goren L, Chen CY. Dynamic reorganization of river basins. Science [serial on the Internet]. 2014; 343(6175):1248765. Available from: https://doi. org/10.1126/science. 1248765
Winn C, Karlstrom KE, Shuster DL, Kelley S, Fox M. 6 Ma age of carving Westernmost Grand Canyon: Reconciling geologic data with combined AFT (U/Th)/He and $4 \mathrm{He} / 3 \mathrm{He}$ thermochronologic data. Earth Planet Sci Lett [serial on the Internet]. 2017; 474:257-71. Available from: https://doi. org/10.1016/j.eps1.2017.06.051

Wintle AG, Adamiec G. Optically stimulated luminescence signals from quartz: A review. Radiat Meas. 2017; 98:10-33.

Wittmann F, Junk WJ. Sapling communities in Amazonian white-water forests. J Biogeogr [serial on the Internet]. 2003; 30(10): 1533-44. Available from: https://doi.org/10.1016/j. radmeas.2017.02.003

Wittmann H, Von Blanckenburg F, Maurice L, Guyot JL, Kubik PW. Recycling of Amazon floodplain sediment quantified by cosmogenic 26Al and 10Be. Geology [serial on the Internet]. 2011; 39(5):467-70. Available from: https://doi.org/10.1130/ G31829.1

Zachos J, Pagani M, Sloan L, Thomas E, Billups K. Trends, rhythms, and aberrations in global climate $65 \mathrm{Ma}$ to present. Science. 2001; 292(5517):686-93.

Submitted March 15, 2018 Accepted September 05, 2018 by Brian Sidlauskas 


\section{ERRATA}

In the Institutional affiliation for Carina Hoorn:

Where read: ${ }^{4}$ Faculteit der Natuurwetenschappen, University of Amsterdam, 1090 GE, Amsterdam, Netherlands Should read: ${ }^{4}$ Institute for Biodiversity and Ecosystem Dynamics, University of Amsterdam, P.O. Box 94248, 1090 GE Amsterdam, The Netherlands

page e180033[9], Caption of Fig. 4:

Where read: a. Early and Middle Miocene (20.4-9.0 Ma). North-trending Sub-Andean river basin orange; east-trending Eastern Amazon river basin yellow. b. Late Miocene (9.0-5.3 Ma). East-trending transcontinental Amazon river basin (Stage 1). c. Middle Pliocene - Recent (c. 4.5-0 Ma).

Should read: a. Early and Middle Miocene (20.4-10.0 Ma). North-trending Sub-Andean river basin orange; east-trending Eastern Amazon river basin yellow. b. Late Miocene (10.0-4.5 Ma). East-trending transcontinental Amazon river basin (Stage 1). c. Middle Pliocene - Recent (c. 4.5-0 Ma).

Neotropical Ichthyology (2019) 17(1): e1901er 